\title{
Allylsilylcyclopentadienyl Group 4 metal complexes: synthesis, structure and reactivity
}

\author{
Jesús Cano, Pilar Gómez-Sal, Georg Heinz, Gema Martínez, Pascual Royo* \\ Departamento de Química Inorgánica, Universidad de Alcalá, Campus Universitario, Edificio de Farmacia, E-28871 Alcalá de Henares, Spain
}

Received 8 April 2002; accepted 10 June 2002

Dedicated to Professor Richard R. Schrock

\begin{abstract}
(Allyldimethyl)silyl-substituted cyclopentadiene $\mathrm{C}_{5} \mathrm{H}_{5} \mathrm{SiMe}_{2}\left(\mathrm{CH}_{2} \mathrm{CH}=\mathrm{CH}_{2}\right.$ ) (1) and indene $\mathrm{C}_{9} \mathrm{H}_{7}-1-\mathrm{SiMe}_{2}\left(\mathrm{CH}_{2} \mathrm{CH}_{2} \mathrm{CH}_{2}\right)(\mathbf{2})$ were synthesized by reaction of $\mathrm{SiMe}_{2}\left(\mathrm{CH}_{2} \mathrm{CH}=\mathrm{CH}_{2}\right) \mathrm{Cl}$ with $\mathrm{NaC}_{5} \mathrm{H}_{5}$ or $\mathrm{LiC}_{9} \mathrm{H}_{7}$, respectively. Metallation of 1 with n-BuLi and TlOEt gave the corresponding lithium 3 and thallium 5 salts. The disilylcylopentadienes $\mathrm{C}_{5} \mathrm{H}_{4}-1-\mathrm{SiMe}_{3}-1-\mathrm{SiMe}_{2}\left(\mathrm{CH}_{2} \mathrm{CH}=\mathrm{CH}_{2}\right)(\mathbf{6})$ and $\mathrm{C}_{5} \mathrm{H}_{4}-1,1-\left[\mathrm{SiMe}_{2}\left(\mathrm{CH}_{2} \mathrm{CH}=\mathrm{CH}_{2}\right)\right]_{2}(7)$ were prepared by reaction of 3 with the corresponding chlorosilanes. Compound 7 reacted with $\mathrm{TiCl}_{4}$ to give the monocyclopentadienyl compound $\left[\mathrm{Ti}\left\{\eta^{5}-\mathrm{C}_{5} \mathrm{H}_{4} \mathrm{SiMe}_{2}\left(\mathrm{CH}_{2} \mathrm{CH}=\mathrm{CH}_{2}\right)\right\} \mathrm{Cl}_{3}\right](\mathbf{8})$, while $\mathbf{5}$ was used to prepare the titanocenes $\left[\mathrm{Ti}\left(\eta^{5}-\mathrm{Cp}\right)\left\{\eta^{5}-\mathrm{C}_{5} \mathrm{H}_{4} \mathrm{SiMe}_{2}\left(\mathrm{CH}_{2} \mathrm{CH}=\mathrm{CH}_{2}\right)\right\} \mathrm{Cl}_{2}\right]\left(\mathrm{Cp}=\mathrm{C}_{5} \mathrm{H}_{4} \mathrm{SiMe}_{2}\left(\mathrm{CH}_{2} \mathrm{CH}=\mathrm{CH}_{2}\right) \mathbf{9}, \mathrm{C}_{5} \mathrm{H}_{5} \mathbf{1 0}, \mathrm{C}_{5} \mathrm{Me}_{5}\right.$ 11) by reaction with the appropriate $\mathrm{TiCpCl}_{3}$ derivative. The related dicyclopentadienyl $\left[\mathrm{Zr}\left\{\eta^{5}-\mathrm{C}_{5} \mathrm{H}_{4} \mathrm{SiMe}_{2}\left(\mathrm{CH}_{2} \mathrm{CH}=\mathrm{CH}_{2}\right)\right\}_{2} \mathrm{Cl}_{2}\right](\mathbf{1 2})$, $\left[\mathrm{Zr}\left(\eta^{5}-\mathrm{C}_{5} \mathrm{H}_{5}\right)\left\{\eta^{5}-\mathrm{C}_{5} \mathrm{H}_{4} \mathrm{SiMe}_{2}\left(\mathrm{CH}_{2} \mathrm{CH}=\mathrm{CH}_{2}\right)\right\} \mathrm{Cl}_{2}\right]$ (13), and indenyl $\left[\mathrm{Zr}\left(\eta^{5}-\mathrm{C}_{5} \mathrm{H}_{5}\right)\left\{\eta^{5}-\mathrm{C}_{9} \mathrm{H}_{6} \mathrm{SiMe}_{2}\left(\mathrm{CH}_{2} \mathrm{CH}=\mathrm{CH}_{2}\right)\right\} \mathrm{Cl}_{2}\right]$ (14) zirconium derivatives were isolated by reaction of $\mathrm{ZrCl}_{4}$ and $\mathrm{Zr}\left(\eta^{5}-\mathrm{C}_{5} \mathrm{H}_{5}\right) \mathrm{Cl}_{3}$. DME with the lithium salts 3 and 4, respectively. Alkylation of the metallocene complexes using MeLi, $\mathrm{MgMeCl}, \mathrm{Mg}\left(\mathrm{CH}_{2} \mathrm{Ph}\right) \mathrm{Cl}$ and $\mathrm{Mg}\left(\mathrm{CH}_{2} \mathrm{Ph}\right)_{2}(\mathrm{THF})_{2}$ afforded the monomethyl titanium $\left[\mathrm{Ti}\left(\eta^{5}-\mathrm{C}_{5} \mathrm{H}_{5}\right)\left\{\eta^{5}-\mathrm{C}_{5} \mathrm{H}_{4} \mathrm{SiMe}_{2}\left(\mathrm{CH}_{2} \mathrm{CH}=\mathrm{CH}_{2}\right)\right\} \mathrm{ClMe}\right](\mathbf{1 5})$ and the dialkyl cyclopentadienyl $\left[\mathrm{M}\left(\eta^{5}-\mathrm{C}_{5} \mathrm{H}_{5}\right)\left\{\eta^{5}-\mathrm{C}_{5} \mathrm{H}_{4} \mathrm{SiMe}_{2}\right.\right.$ $\left.\left.\left(\mathrm{CH}_{2} \mathrm{CH}=\mathrm{CH}_{2}\right)\right\} \mathrm{R}_{2}\right]\left(\mathrm{R}=\mathrm{Me}, \mathrm{M}=\mathrm{Ti} \mathbf{1 6}, \mathrm{Zr} \mathbf{1 8} ; \mathrm{R}=\mathrm{CH}_{2} \mathrm{Ph}, \mathrm{M}=\mathrm{Ti} \mathbf{2 0}, \mathrm{Zr} \mathbf{2 2}\right),\left[\mathrm{Zr}\left\{\eta^{5}-\mathrm{C}_{5} \mathrm{H}_{4} \mathrm{SiMe}_{2}\left(\mathrm{CH}_{2} \mathrm{CH}=\mathrm{CH}_{2}\right)\right\}_{2} \mathrm{R}_{2}\right](\mathrm{R}=\mathrm{Me}$ 17, $\left.\mathrm{CH}_{2} \mathrm{Ph} 21\right)$ and indenyl derivatives $\left[\mathrm{Zr}\left(\eta^{5}-\mathrm{C}_{5} \mathrm{H}_{5}\right)\left\{\eta^{5}-\mathrm{C}_{9} \mathrm{H}_{6} \mathrm{SiMe}_{2}\left(\mathrm{CH}_{2} \mathrm{CH}=\mathrm{CH}_{2}\right)\right\} \mathrm{R}_{2}\right]\left(\mathrm{R}=\mathrm{Me}\right.$ 19, $\mathrm{CH}_{2} \mathrm{Ph}$ 23). The molecular structure of $\mathbf{1 1}$ was studied by X-ray diffraction methods. The reactions of the dialkyl derivatives with $\mathrm{B}\left(\mathrm{C}_{6} \mathrm{~F}_{5}\right)_{3}$ were monitored by NMR spectroscopy at variable temperature. The catalytic activity of the dichloro zirconium complexes in the presence of methylalumoxane (MAO) for ethylene polymerization was determined.
\end{abstract}

(C) 2002 Elsevier Science B.V. All rights reserved.

Keywords: Metallocene; Titanium; Zirconium; Polymerization; Cationic species

\section{Introduction}

Numerous studies on the synthesis and characterization of dicyclopentadienyl cationic Group 4 metal alkyls have been reported [1] based on the general agreement that this type of 14-electron system is the active species in $\alpha$-olefin polymerization reactions [2]. They are formed when the precursor dicyclopentadienylmetal dichloride is treated with excess alkylating agent and strong Lewis acid methylalumoxane (MAO), or when dialkyl deriva-

\footnotetext{
* Corresponding author. Tel.: +34-91-885 4765; fax: +34-91-885 4683

E-mail address: pascual.royo@uah.es (P. Royo).
}

tives are treated with dealkylating agents such as $\left[\mathrm{Ph}_{3} \mathrm{C}\right]^{+}$or $\mathrm{B}\left(\mathrm{C}_{6} \mathrm{~F}_{5}\right)_{3}$. Under these conditions the generated counteranion (MAO-R ${ }^{-},\left[\mathrm{B}\left(\mathrm{C}_{6} \mathrm{~F}_{5}\right)_{4}\right]^{-}$or $\left[\mathrm{RB}\left(\mathrm{C}_{6} \mathrm{~F}_{5}\right)_{3}\right]^{-}$, respectively) is weakly coordinated to the metal cation through interionic contacts or residual alkyl and fluorine interactions. As the olefin has an extremely weak coordinating capacity, these interactions need to be as weak as possible to allow the olefin to coordinate to the metal centre and insert into the metalalkyl bond to promote polymeric chain lengthening. Free active 14-electron metal cations do not exist and even when no interactions with the counterion are observed, they are stabilized by coordination of a second molecule of the dialkyl complex to give dinuclear cations or through some type of intramolecular agostic 
interaction. Efforts have also been made to obtain welldefined single-component zwitterionic catalysts containing the counterion chemically attached to the cyclopentadienyl ring [3].

Several attempts have been made to isolate or characterize the key alkene coordinated $\mathrm{d}^{0}$ metal cation present immediately before the insertion step [4]. We reported [5] that the allylsilyl-substituted cyclopentadienyl ring is a convenient ligand to favour $\eta^{2}$-coordination of the alkene moiety when cationic species are generated by reaction of the prochiral dialkyl Group 4 metallocenes with boron based Lewis acids.

We report here the isolation and characterization of Group 4 metallocene-type complexes containing this ligand, studies related to their cationic derivatives and ethylene polymerization activities and the X-ray molecular structure of the titanium complex $\left[\mathrm{Ti}\left(\eta^{5}-\right.\right.$ $\left.\left.\mathrm{C}_{5} \mathrm{H}_{5}\right)\left\{\eta^{5}-\mathrm{C}_{5} \mathrm{H}_{4} \mathrm{SiMe}_{2}\left(\mathrm{CH}_{2} \mathrm{CH}=\mathrm{CH}_{2}\right)\right\} \mathrm{Cl}_{2}\right]$.

\section{Results and discussion}

\subsection{Synthesis of ring transfer agents and chloro complexes}

The straightforward preparation of the substituted (allyldimethyl)silylcyclopentadiene $\quad \mathrm{C}_{5} \mathrm{H}_{5} \mathrm{SiMe}_{2}\left(\mathrm{CH}_{2}-\right.$ $\left.\mathrm{CH}=\mathrm{CH}_{2}\right) \mathbf{1}$ was easily achieved in high yield by an improved synthesis based on the reaction of (allyldimethyl)chlorosilane with $\mathrm{NaCp}$ in hexane rather than the reported [6] allylation of the corresponding cyclopentadienylchlorosilane. Compound $\mathbf{1}$ was isolated as a yellow liquid in $86 \%$ yield, which freshly prepared can be stored at $-40{ }^{\circ} \mathrm{C}$ without dimerization. According to its ${ }^{1} \mathrm{H}$ NMR spectrum the isolated 1 consists of a mixture of two isomers due to the well known silatropic rearrangement, the isomer with the silyl group bound to the $\mathrm{sp}^{3}$ carbon being the major component. As shown in Scheme 1, a similar reaction with $\mathrm{LiC}_{9} \mathrm{H}_{7}$ afforded the silylindene $\mathrm{C}_{9} \mathrm{H}_{7}-1-\mathrm{SiMe}_{2}\left(\mathrm{CH}_{2} \mathrm{CH}=\mathrm{CH}_{2}\right)(2)$ which was isolated in hexane as a yellow liquid in $69 \%$ yield after distillation. According to its ${ }^{1} \mathrm{H}$ NMR spectrum it contains a unique 1-substituted isomer.
The lithium salts $\mathrm{Li}\left[\mathrm{C}_{5} \mathrm{H}_{4} \mathrm{SiMe}_{2}\left(\mathrm{CH}_{2} \mathrm{CH}=\mathrm{CH}_{2}\right)\right]$ (3) and $\mathrm{Li}\left[\mathrm{C}_{9} \mathrm{H}_{6}-1-\mathrm{SiMe}_{2}\left(\mathrm{CH}_{2} \mathrm{CH}=\mathrm{CH}_{2}\right)\right](4)$ were the most convenient reagents to prepare zirconium derivatives. They were formed by ring deprotonation with $\mathrm{n}-\mathrm{BuLi}$ in THF and their solutions were used in situ without further characterization. The thallium salt $\mathrm{Tl}\left[\mathrm{C}_{5} \mathrm{H}_{4} \mathrm{SiMe}_{2}\left(\mathrm{CH}_{2} \mathrm{CH}=\mathrm{CH}_{2}\right)\right]$ (5) and the disilyl derivatives $\mathrm{C}_{5} \mathrm{H}_{4}-1-\mathrm{SiMe}_{3}-1-\mathrm{SiMe}_{2}\left(\mathrm{CH}_{2} \mathrm{CH}=\mathrm{CH}_{2}\right)(6)$ and $\mathrm{C}_{5} \mathrm{H}_{4}-1,1-\left[\mathrm{SiMe}_{2}\left(\mathrm{CH}_{2} \mathrm{CH}=\mathrm{CH}_{2}\right)\right]_{2}$ (7) were required to isolate the titanium compounds. The thallium derivative $\mathbf{5}$ was prepared using TlOEt as deprotonating agent and was isolated in $92 \%$ yield as a colourless solid scarcely soluble in hexane but soluble in toluene and polar solvents. It was characterized by elemental analysis and NMR spectroscopy (see Section 4).

The disilylcyclopentadiene compound $\mathbf{6}$ was prepared by reaction of the lithium salt 3 with $\mathrm{SiClMe}_{3}$. Reaction of 6 with $\mathrm{TiCl}_{4}$ afforded a mixture of $\left[\mathrm{Ti}\left\{\eta^{5}\right.\right.$ $\left.\left.\mathrm{C}_{5} \mathrm{H}_{4} \mathrm{SiMe}_{2}\left(\mathrm{CH}_{2} \mathrm{CH}=\mathrm{CH}_{2}\right)\right\} \mathrm{Cl}_{3}\right](\mathbf{8})$ and $\left[\mathrm{Ti}\left(\eta^{5}-\mathrm{C}_{5} \mathrm{H}_{4} \mathrm{Si}-\right.\right.$ $\left.\mathrm{Me}_{3}\right) \mathrm{Cl}_{3}$ ] in a molar ratio of about $3 / 2$, demonstrating that unselective attack to both silyl groups takes place [7]. In order to prepare 8 in better yield, avoiding separation problems, we decided to use the symmetric disilylcyclopentadiene $\quad \mathrm{C}_{5} \mathrm{H}_{4}-1,1-\left[\mathrm{SiMe}_{2}\left(\mathrm{CH}_{2} \mathrm{CH}=\right.\right.$ $\left.\mathrm{CH}_{2}\right)_{2}$ (7) which was isolated as a yellow liquid in high yield by a similar reaction of $\mathbf{3}$ with the (allyldimethyl)chlorosilane.

As shown in Scheme 2, the reaction of $\mathrm{TiCl}_{4}$ with 1 equiv. of the disilylcyclopentadiene 7 afforded the monocyclopentadienyl titanium complex $\left[\mathrm{Ti}\left\{\eta^{5}\right.\right.$ $\left.\left.\mathrm{C}_{5} \mathrm{H}_{4} \mathrm{SiMe}_{2}\left(\mathrm{CH}_{2} \mathrm{CH}=\mathrm{CH}_{2}\right)\right\} \mathrm{Cl}_{3}\right](\mathbf{8})$, isolated as a yellow crystalline solid by cooling its hexane solution to $-35{ }^{\circ} \mathrm{C}$, which became a yellow oil at room temperature and was characterized by elemental analysis and NMR spectroscopy. Treatment of a toluene solution of complex $\mathbf{8}$ with the thallium salt $\mathbf{5}$ gave the dicyclopentadienyl derivative $\left[\mathrm{Ti}\left\{\eta^{5}-\mathrm{C}_{5} \mathrm{H}_{4} \mathrm{SiMe}_{2}\left(\mathrm{CH}_{2} \mathrm{CH}=\right.\right.\right.$ $\left.\left.\mathrm{CH}_{2}\right)\right\}_{2} \mathrm{Cl}_{2}$ ] (9), which was isolated in $63 \%$ yield as a red solid after recrystallization from hexane.

The mixed dicyclopentadienyl titanium complexes $\left[\mathrm{Ti}\left(\eta^{5}-\mathrm{Cp}\right)\left\{\eta^{5}-\mathrm{C}_{5} \mathrm{H}_{4} \mathrm{SiMe}_{2}\left(\mathrm{CH}_{2} \mathrm{CH}=\mathrm{CH}_{2}\right)\right\} \mathrm{Cl}_{2}\right] \quad(\mathrm{Cp}=$ $\mathrm{C}_{5} \mathrm{H}_{5} 10, \mathrm{C}_{5} \mathrm{Me}_{5} 11$ ) were prepared by reaction of the corresponding $\left[\mathrm{TiCpCl}_{3}\right]$ derivative with 1 equiv. of the thallium salt $\mathbf{5}$ in toluene. Both complexes were isolated

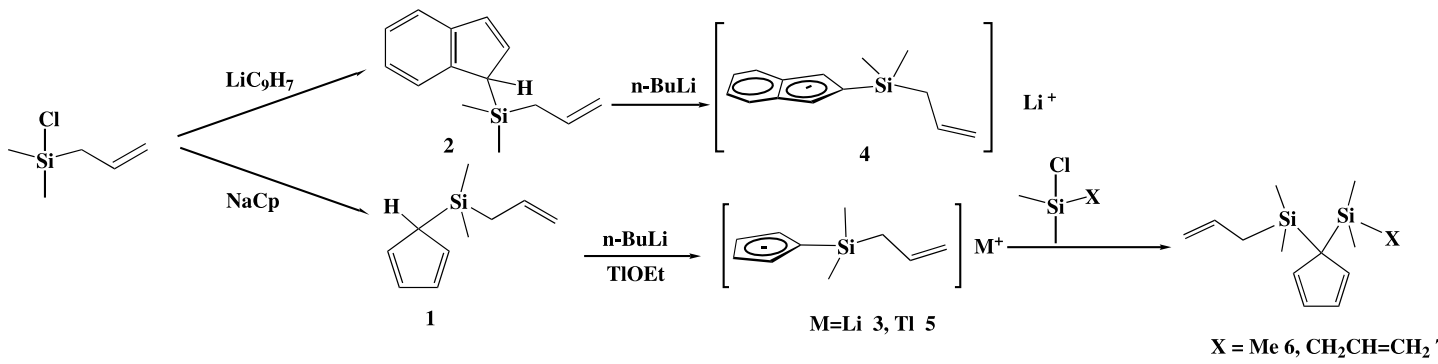

Scheme 1. 


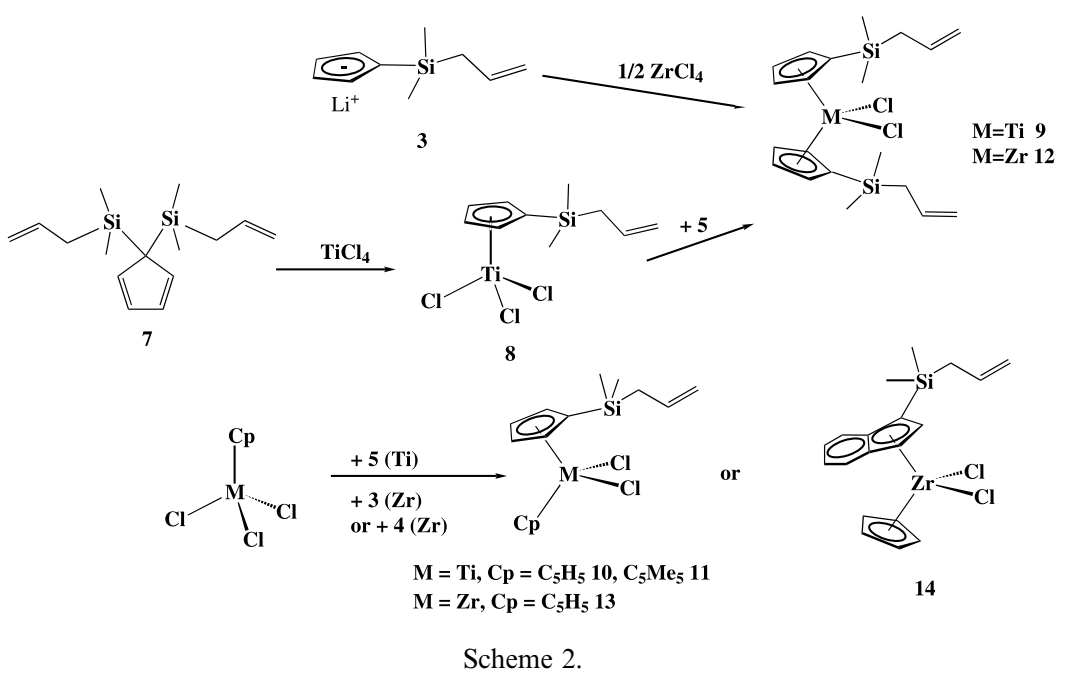

as red crystalline solids by cooling their hexane solutions to $-35{ }^{\circ} \mathrm{C}$ and were identified by elemental analysis and NMR spectroscopy (see Section 4).

However, the lithium salt 3 was the best reagent to transfer the ring to the zirconium $\left[\mathrm{ZrCpCl}_{3}\right]$ compound. Similar reactions of $\mathrm{ZrCl}_{4}$ with 2 equiv. of the lithium salt 3 and of $\left[\mathrm{Zr}\left(\eta^{5}-\mathrm{C}_{5} \mathrm{H}_{5}\right) \mathrm{Cl}_{3} \cdot \mathrm{DME}\right]$ with 1 equiv. of 3 and 4 in THF gave the dicyclopentadienyl complexes $\left[\mathrm{Zr}\left\{\eta^{5}-\mathrm{C}_{5} \mathrm{H}_{4} \mathrm{SiMe}_{2}\left(\mathrm{CH}_{2} \mathrm{CH}=\mathrm{CH}_{2}\right)\right\}_{2} \mathrm{Cl}_{2}\right] \quad$ (12) and $\left[\mathrm{Zr}\left(\eta^{5}-\mathrm{C}_{5} \mathrm{H}_{5}\right)\left\{\eta^{5}-\mathrm{C}_{5} \mathrm{H}_{4} \mathrm{SiMe}_{2}\left(\mathrm{CH}_{2} \mathrm{CH}=\mathrm{CH}_{2}\right)\right\} \mathrm{Cl}_{2}\right]$ and the indenyl zirconium derivative $\left[\mathrm{Zr}\left(\eta^{5}-\mathrm{C}_{5} \mathrm{H}_{5}\right)\left\{\eta^{5}\right.\right.$ $\left.\left.\mathrm{C}_{9} \mathrm{H}_{6} \mathrm{SiMe}_{2}\left(\mathrm{CH}_{2} \mathrm{CH}=\mathrm{CH}_{2}\right)\right\} \mathrm{Cl}_{2}\right] \quad$ (14), respectively. Complexes 12-13 were isolated as colourless crystalline solids and $\mathbf{1 4}$ as a yellow solid after recrystallization from toluene/hexane. The indenyl complex was more air sensitive than the cyclopentadienyl derivatives although all of them can be stored without transformation for long periods under argon.

\subsection{Synthesis of alkyl complexes}

As shown in Scheme 3 methylation of the dicyclopentadienyl titanium complex 10 with 1 equiv. of a $3 \mathrm{M}$ THF solution of $\mathrm{MgClMe}$ gave the partially methylated compound $\quad\left[\mathrm{Ti}\left(\eta^{5}-\mathrm{C}_{5} \mathrm{H}_{5}\right)\left\{\eta^{5}-\mathrm{C}_{5} \mathrm{H}_{4} \mathrm{SiMe}_{2}\left(\mathrm{CH}_{2} \mathrm{CH}=\right.\right.\right.$ $\left.\left.\mathrm{CH}_{2}\right)\right\} \mathrm{ClMe}$ (15) in high yield, whereas addition of 2 equiv. afforded the dimethyl complex $\left[\mathrm{Ti}\left(\eta^{5}-\mathrm{C}_{5} \mathrm{H}_{5}\right)\left\{\eta^{5}-\right.\right.$ $\left.\left.\mathrm{C}_{5} \mathrm{H}_{4} \mathrm{SiMe}_{2}\left(\mathrm{CH}_{2} \mathrm{CH}=\mathrm{CH}_{2}\right)\right\} \mathrm{Me}_{2}\right]$ (16). The related zirconium derivatives 12-14 were methylated with diethylether solutions of $\mathrm{LiMe}$ to give the corresponding dimethyl compounds $\left[\mathrm{Zr}\left\{\eta^{5}-\mathrm{C}_{5} \mathrm{H}_{4} \mathrm{SiMe}_{2}\left(\mathrm{CH}_{2} \mathrm{CH}=\right.\right.\right.$ $\left.\left.\left.\mathrm{CH}_{2}\right)\right\}_{2} \mathrm{Me}_{2}\right]$ (17), $\quad\left[\mathrm{Zr}\left(\eta^{5}-\mathrm{C}_{5} \mathrm{H}_{5}\right)\left\{\eta^{5}-\mathrm{C}_{5} \mathrm{H}_{4} \mathrm{SiMe}_{2}\left(\mathrm{CH}_{2}-\right.\right.\right.$ $\left.\left.\left.\mathrm{CH}=\mathrm{CH}_{2}\right)\right\} \mathrm{Me}_{2}\right](\mathbf{1 8})$ and $\left[\mathrm{Zr}\left(\eta^{5}-\mathrm{C}_{5} \mathrm{H}_{5}\right)\left\{\eta^{5}-\mathrm{C}_{9} \mathrm{H}_{6} \mathrm{SiMe}_{2}\right.\right.$ $\left.\left.\left(\mathrm{CH}_{2} \mathrm{CH}=\mathrm{CH}_{2}\right)\right\} \mathrm{Me}_{2}\right]$ (19), respectively. Compound $\mathbf{1 5}$ was isolated as a red-orange crystalline solid whereas all of the dimethyl derivatives were obtained as orange (16), brown (17), colourless (18) and yellow (19) oils at room temperature. The oily compounds turned into waxy solids which could not be crystallized by cooling to
$-78{ }^{\circ} \mathrm{C}$. All of the methyl complexes $\mathbf{1 5}-19$ are extremely air sensitive compounds, very soluble in all organic solvents, which can be stored under argon for long periods.

Similar reactions of the dichloro metal complexes $\mathbf{1 0}$ and 12-14 with stoichiometric amounts of $\mathrm{MgCl}\left(\mathrm{CH}_{2} \mathrm{Ph}\right)$ and $\mathrm{Mg}\left(\mathrm{CH}_{2} \mathrm{Ph}\right)_{2} \cdot 2 \mathrm{THF}$ afforded the dibenzyl titanium complex $\left[\mathrm{Ti}\left(\eta^{5}-\mathrm{C}_{5} \mathrm{H}_{5}\right)\left\{\eta^{5}-\right.\right.$ $\left.\left.\mathrm{C}_{5} \mathrm{H}_{4} \mathrm{SiMe}_{2}\left(\mathrm{CH}_{2} \mathrm{CH}=\mathrm{CH}_{2}\right)\right\}\left(\mathrm{CH}_{2} \mathrm{Ph}\right)_{2}\right]$ (20), isolated as a dark red solid, the dicyclopentadienyl zirconium complexes $\quad\left[\mathrm{Zr}\left\{\eta^{5}-\mathrm{C}_{5} \mathrm{H}_{4} \mathrm{SiMe}_{2}\left(\mathrm{CH}_{2} \mathrm{CH}=\mathrm{CH}_{2}\right)\right\}_{2}\left(\mathrm{CH}_{2}-\right.\right.$ $\left.\mathrm{Ph})_{2}\right]$ (21), as a yellow orange oil and $\left[\operatorname{Zr}\left(\eta^{5}\right.\right.$ $\left.\left.\mathrm{C}_{5} \mathrm{H}_{5}\right)\left\{\eta^{5}-\mathrm{C}_{5} \mathrm{H}_{4} \mathrm{SiMe}_{2}\left(\mathrm{CH}_{2} \mathrm{CH}=\mathrm{CH}_{2}\right)\right\}\left(\mathrm{CH}_{2} \mathrm{Ph}\right)_{2}\right]$ as a yellow-orange solid, and the indenyl $\left[\mathrm{Zr}\left(\eta^{5}\right.\right.$ $\left.\left.\mathrm{C}_{5} \mathrm{H}_{5}\right)\left\{\eta^{5}-\mathrm{C}_{9} \mathrm{H}_{6} \mathrm{SiMe}_{2}\left(\mathrm{CH}_{2} \mathrm{CH}=\mathrm{CH}_{2}\right)\right\}\left(\mathrm{CH}_{2} \mathrm{Ph}\right)_{2}\right]$ derivative isolated as an orange microcrystalline solid, respectively. All were very air sensitive and very soluble in all organic solvents and were recrystallized from hexane and stored under argon without decomposition for long periods.

\subsection{Structural studies: NMR spectroscopy and X-ray molecular structure of complex 11}

Detailed analytical and NMR spectroscopic data for all of the new complexes are given in Section 4. The ${ }^{1} \mathrm{H}$ NMR spectra of all the complexes show the typical pattern of the allyl substituent which comprises one high field doublet for the $\mathrm{Si}-\mathrm{CH}_{2}$ protons at $\delta 1.3-1.9$ with $J_{\mathrm{H}-\mathrm{H}}=7.9-8.6 \mathrm{~Hz}$, one multiplet at $\delta 5.5-5.8$ for the internal olefinic proton and one multiplet for the two external olefinic protons at $\delta 4.8-4.9$. This is consistent with the ${ }^{13} \mathrm{C}\left\{{ }^{1} \mathrm{H}\right\}$ spectra which show one high field signal at $\delta 23-25$ and two low field resonances between $\delta 113$ and 125 . This behaviour provides evidence for the presence of the free uncoordinated pendant alkene moiety.

The protons of the substituted cyclopentadienyl ring are observed as two multiplets corresponding to a 


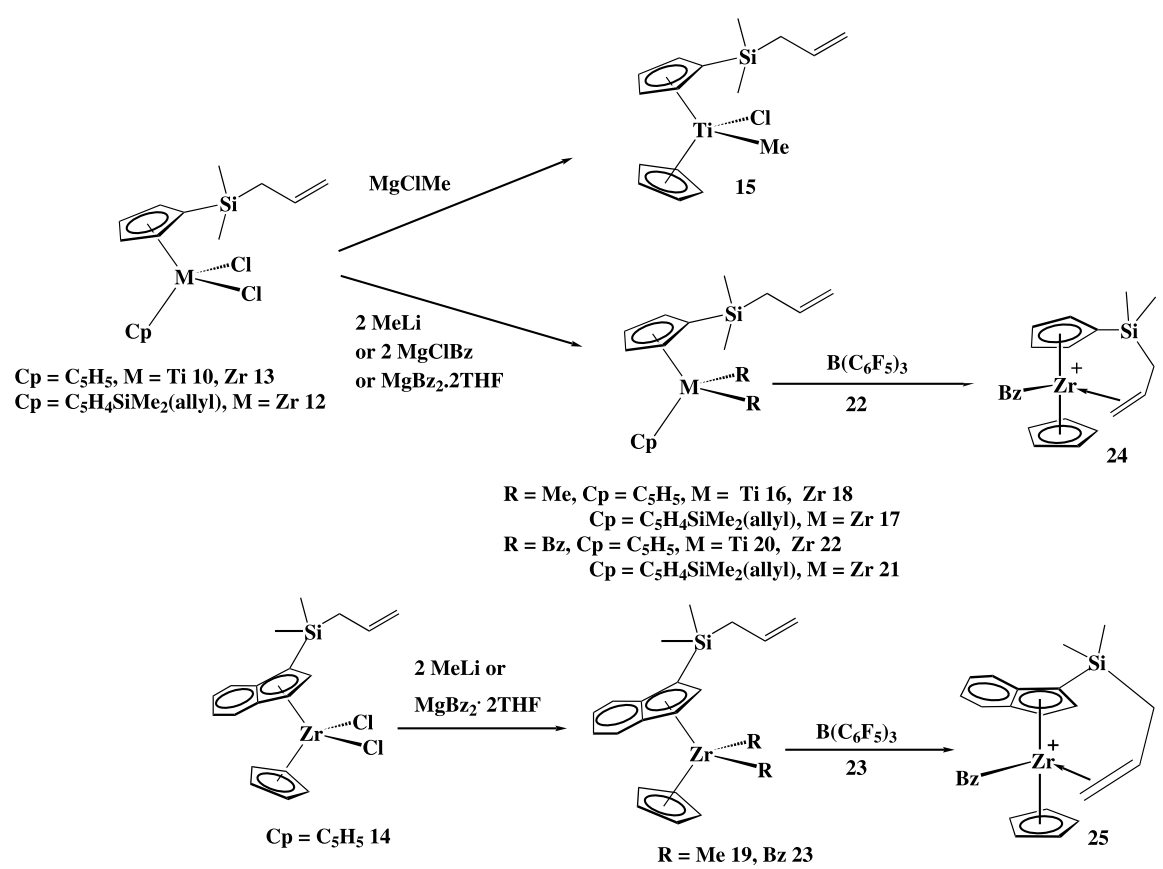

Scheme 3.

$\mathrm{AA}^{\prime} \mathrm{BB}^{\prime}$ spin system for the monocyclopentadienyl titanium complex 8 and for all of the dicyclopentadienyl dichloro 9-13, dimethyl 16-18 and dibenzyl 20-22 complexes which have a plane of symmetry. Accordingly three resonances are observed for the ring carbons of these compounds in their ${ }^{13} \mathrm{C}\left\{{ }^{1} \mathrm{H}\right\}$ spectra. However, the methyl-chloro titanium complex $\mathbf{1 5}$ is an asymmetric molecule with a chiral metal centre, making the ring protons non-equivalent and evident as four multiplets corresponding to an ABCD spin system with five resonances observed for the ring carbons in its ${ }^{13} \mathrm{C}\left\{{ }^{1} \mathrm{H}\right\}$ spectrum. Complex 15 also shows two nonequivalent $\mathrm{SiMe}_{2}$ groups, whereas all of the other, dichloro, dimethyl and dibenzyl complexes show one unique singlet. The resonance due to the methyl metalbound groups is observed in the ${ }^{1} \mathrm{H}$ and ${ }^{13} \mathrm{C}$ NMR spectra as one singlet for the mono- (15) and dimethyl (16-18) dicyclopentadienyl complexes displaced to higher field in the expected order $\mathrm{CpTi}<\mathrm{Cp}_{2} \mathrm{Ti}<$ $\mathrm{Cp}_{2} \mathrm{Zr}$. The prochiral character of the metal centre in the dibenzyl derivatives 20, 22 makes the two diastereotopic methylenic protons appear as two doublets for the titanium complex 20, whereas one multiplet is observed for the zirconium derivative 22 .

The two cyclopentadienyl protons of the indenyl ligand in complexes 14, 19 and 23 are not equivalent, being observed as two multiplets. This behaviour confirms that the silyl substituent is bound to the ring $\mathrm{C}-1$ atom, inducing the chirality responsible for the nonequivalence of the two silicon-bound $(\mathbf{1 4}, \mathbf{1 9}$ and $\mathbf{2 3})$ and zirconium-bound methyl groups in complex 19. The two benzyl ligands in complex $\mathbf{2 3}$ are also not equivalent and consequently their two pairs of methylenic benzyl protons are observed as four doublets between $\delta 1.22$ and 1.85. The ${ }^{13} \mathrm{C}\left\{{ }^{1} \mathrm{H}\right\}$ NMR spectra are consistent with this formulation.

Additionally the expected singlets due to the ring protons of the unsubstituted cyclopentadienyl ring and to the methyl protons of the permethylated ring are observed in the ${ }^{1} \mathrm{H}$ and ${ }^{13} \mathrm{C}$ NMR spectra of the corresponding complexes.

Single crystals of the mixed dicyclopentadienyl dichloro complex $\mathbf{1 1}$ appropriate for X-ray diffraction studies were isolated by crystallization from pentane. A drawing of $\mathbf{1 1}$ based on the X-ray structural analysis with the atomic labelling scheme is shown in Fig. 1 and selected bond distances and angles are given in Table 1 .

The molecule has the typical bent-metallocene structure with the titanium atom in a pseudotetrahedral coordination defined by the centroid of the cyclopentadienyl rings and the two chlorine atoms. The molecule is very similar to those reported for related compounds [ $\mathrm{Ti}\left(\mathrm{C}_{5} \mathrm{H}_{5}\right)\left(\mathrm{C}_{5} \mathrm{Me}_{5}\right) \mathrm{Cl}_{2}$ ] [8] and [ $\mathrm{Ti}\left(\mathrm{C}_{5} \mathrm{Me}_{5}\right)_{2} \mathrm{Cl}_{2}$ ] [9]. Complex 11 shows $\mathrm{Ti}-\mathrm{Cl}$ (2.335(2) and 2.344(2) $\AA$ ) distances of the same order as those observed previously and the $\mathrm{Cl1}-\mathrm{Ti}-\mathrm{Cl} 2$ angle $\left(94.39(7)^{\circ}\right)$ has the value expected for $d^{0}$ complexes. The distances from the titanium atom to the $\mathrm{Cp}$ centroids $\left(\mathrm{Ti}-\mathrm{Cp}^{*}, 2.109 \AA\right.$ and $\mathrm{Ti}-\mathrm{CpSi}, 2.079$ $\AA$ ) and the mean distance to the ring carbon atoms ( $\mathrm{Ti}-$ $\mathrm{Cp}^{*}, 2.417 \AA$ and $\mathrm{Ti}-\mathrm{CpSi}, 2.393 \AA$ ) are very close to the reported values. However, the silyl-substituted ring is clearly distorted showing two shorter $\mathrm{Ti}-\mathrm{C}(13)$ and $\mathrm{Ti}-\mathrm{C}(14)(2.344(5) \AA)$ and one larger Ti-C(11) (2.466(4) $\AA)$ distances. The $\mathrm{Cp}-\mathrm{Ti}-\mathrm{Cp}\left(132.1^{\circ}\right)$ angle is similar to that observed in $\left[\mathrm{Ti}\left(\mathrm{C}_{5} \mathrm{H}_{5}\right)\left(\mathrm{C}_{5} \mathrm{Me}_{5}\right) \mathrm{Cl}_{2}\right]\left(131.9^{\circ}\right)$ but closer than the angle reported for $\left[\mathrm{Ti}\left(\mathrm{C}_{5} \mathrm{Me}_{5}\right)_{2} \mathrm{Cl}_{2}\right]$ 


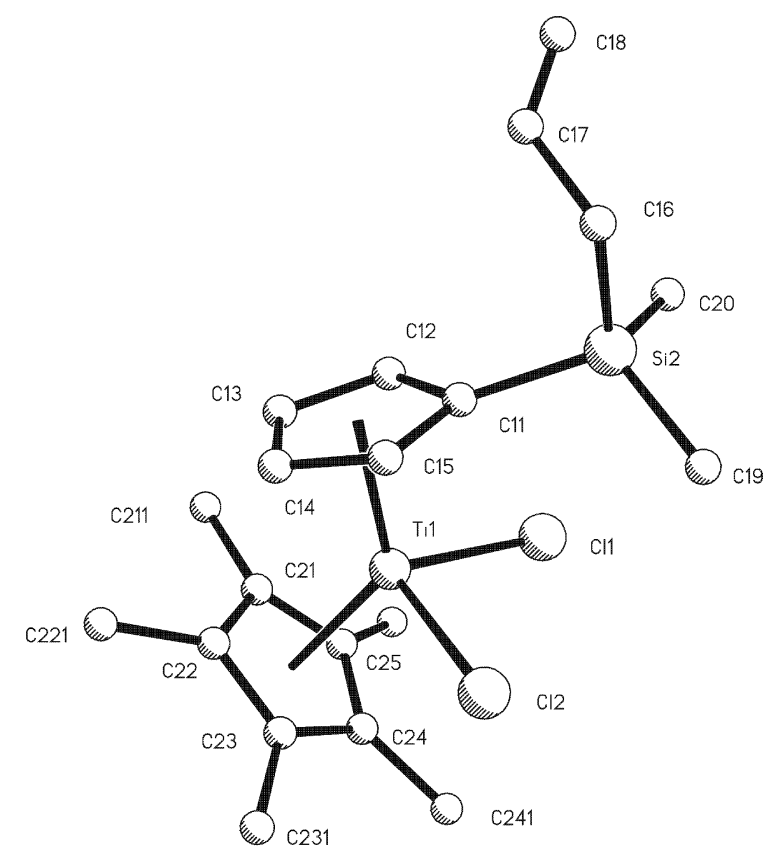

Fig. 1. Perspective view of complex 11 showing the atom numbering scheme.

Table 1

Bond lengths $(\AA)$ and angles $\left({ }^{\circ}\right)$ for $\mathbf{1 1}$

\begin{tabular}{lcll}
\hline Bond lengths & & & \\
$\mathrm{Ti}(1)-\mathrm{Cl}(1)$ & $2.335(2)$ & $\mathrm{Ti}(1)-\mathrm{Cl}(2)$ & $2.344(2)$ \\
$\mathrm{Ti}(1)-\mathrm{C}(15)$ & $2.423(5)$ & $\mathrm{Ti}(1)-\mathrm{C}(14)$ & $2.344(6)$ \\
$\mathrm{Ti}(1)-\mathrm{C}(13)$ & $2.344(5)$ & $\mathrm{Ti}(1)-\mathrm{C}(12)$ & $2.386(5)$ \\
$\mathrm{Ti}(1)-\mathrm{C}(11)$ & $2.466(4)$ & $\mathrm{Ti}(1)-\mathrm{C}(21)$ & $2.393(5)$ \\
$\mathrm{Ti}(1)-\mathrm{C}(22)$ & $2.410(5)$ & $\mathrm{Ti}(1)-\mathrm{C}(23)$ & $2.431(5)$ \\
$\mathrm{Ti}(1)-\mathrm{C}(24)$ & $2.421(5)$ & $\mathrm{Ti}(1)-\mathrm{C}(25)$ & $2.432(5)$ \\
$\mathrm{C}(11)-\mathrm{C}(15)$ & $1.412(7)$ & $\mathrm{C}(11)-\mathrm{C}(12)$ & $1.413(7)$ \\
$\mathrm{C}(12)-\mathrm{C}(13)$ & $1.409(9)$ & $\mathrm{C}(13)-\mathrm{C}(14)$ & $1.354(9)$ \\
$\mathrm{C}(14)-\mathrm{C}(15)$ & $1.382(9)$ & $\mathrm{C}(21)-\mathrm{C}(25)$ & $1.373(8)$ \\
$\mathrm{C}(21)-\mathrm{C}(22)$ & $1.406(8)$ & $\mathrm{C}(22)-\mathrm{C}(23)$ & $1.392(8)$ \\
$\mathrm{C}(23)-\mathrm{C}(24)$ & $1.405(8)$ & $\mathrm{C}(24)-\mathrm{C}(25)$ & $1.374(8)$ \\
$\mathrm{C}(16)-\mathrm{C}(17)$ & $1.494(10)$ & $\mathrm{C}(17)-\mathrm{C}(18)$ & $1.206(10)$ \\
$\mathrm{Ti}(1)-\mathrm{Cp}(1)$ & 2.079 & $\mathrm{Ti}(1)-\mathrm{Cp}(2)$ & 2.109 \\
Bond angles & & & \\
$\mathrm{Cl}(1)-\mathrm{Ti}(1)-\mathrm{Cl}(2)$ & $94.39(7)$ & $\mathrm{Cp}(1)-\mathrm{Ti}(1)-\mathrm{Cp}(2)$ & 132.1 \\
$\mathrm{Cp}(1)-\mathrm{Ti}(1)-\mathrm{Cl}(1)$ & 106.3 & $\mathrm{Cp}(1)-\mathrm{Ti}(1)-\mathrm{Cl}(2)$ & 105.9 \\
$\mathrm{Cp}(2)-\mathrm{Ti}(1)-\mathrm{Cl}(1)$ & 106.3 & $\mathrm{Cp}(2)-\mathrm{Ti}(1)-\mathrm{Cl}(2)$ & 105.5 \\
\end{tabular}

$\mathrm{Cp}(1)$ is the centroid of $\mathrm{C} 11, \mathrm{C} 12, \mathrm{C} 13, \mathrm{C} 14, \mathrm{C} 15$ and $\mathrm{Cp}(2)$ is the centroid of $\mathrm{C} 21, \mathrm{C} 22, \mathrm{C} 23, \mathrm{C} 24, \mathrm{C} 25$.

$\left(137.4^{\circ}\right)$. The location of the silyl substituent in the plane bisecting the $\mathrm{Cl}-\mathrm{Ti}-\mathrm{Cl}$ angle and the orientation of the allyl moiety out of the equatorial plane is favoured by the steric requirements of both cyclopentadienyl rings. The $\mathrm{C}(16)-\mathrm{C}(17) \quad(1.494(10) \quad \AA)$ and $\mathrm{C}(17)-\mathrm{C}(18)$ (1.206(10) A) distances correspond to single and double bonds, respectively and all the remaining $\mathrm{C}-\mathrm{C}$ and $\mathrm{Si}-\mathrm{C}$ distances have normal values.

\subsection{Studies related to cationic species}

An earlier communication reported [5] the results observed when the dibenzyl zirconium complex 22 was reacted with either the Lewis acid tris(pentafluorophenyl)boron $\mathrm{B}\left(\mathrm{C}_{6} \mathrm{~F}_{5}\right)_{3}$ or $\left[\mathrm{CPh}_{3}\right]\left[\mathrm{B}\left(\mathrm{C}_{6} \mathrm{~F}_{5}\right)_{4}\right]$. We demonstrated the formation of the cationic species $\left[\mathrm{Zr}\left(\eta^{5}\right.\right.$ $\left.\mathrm{C}_{5} \mathrm{H}_{5}\right)\left(\eta^{5}-\mathrm{C}_{5} \mathrm{H}_{4}\left\{\mathrm{SiMe}_{2}\left(\eta^{2}-\mathrm{CH}_{2} \mathrm{CH}=\mathrm{CH}_{2}\right)\right\}\left(\mathrm{CH}_{2} \mathrm{Ph}\right)\right]^{+}$

24, which showed $C_{2 v}$ symmetry for the phenyl ring, indicating that its stabilization is not due to benzallylic distortion [2e] but to the $\eta^{2}$-coordination of the alkene moiety favoured by the long and fluxional pendant chain of the silyl substituent. The presence of a chiral metal centre and the enantiotopic face of the alkene give rise to two diastereomers in complex $\mathbf{2 4}$ however only one $\mathrm{Cp}$ resonance was observed in the ${ }^{1} \mathrm{H}$ and ${ }^{13} \mathrm{C}$ NMR spectra of 24 at $-80{ }^{\circ} \mathrm{C}$. This behaviour would be consistent either with the formation of only one exo- or endo-isomer or more probably, with rapid interconversion on the NMR time scale between the two diastereomers via dissociation of the alkene followed by recomplexation to the opposite alkene enantioface. The metal-olefin system could be described as a dative interaction from the highly polarized olefinic moiety with a significant electrostatic contribution. Energy differences between the exo- and endo-isomers should be small. However, the barrier for dissociation of the silyl-allyl alkene moiety bonded to zirconium would be expected to be lower than values previously reported $[4,10]$ for other chelated olefins. The dynamic behaviour observed for complex 24 between -80 and $-10{ }^{\circ} \mathrm{C}$ was therefore attributed [5] to the reversible interconversion between two enantiomers by alkene dissociation combined with inversion at zirconium. From variable temperature NMR experiments values of $\Delta G^{\star}=11.4$ $\mathrm{kcal} \mathrm{mol}{ }^{-1}$ and $E_{\mathrm{a}}=13.4 \pm 0.54 \mathrm{kcal} \mathrm{mol}^{-1}$ were calculated for interconversion between the two enantiomers through a $C_{s}$ symmetric transition state, consistent with theoretical data reported by other authors $[4,10]$.

We have extended the same study to some of the Group 4 metal alkyl derivatives for which single cationic species could also be identified. All of these studies were carried out following the reactions of appropriate samples in $\mathrm{CD}_{2} \mathrm{Cl}_{2}$ solutions in sealed NMR tubes by ${ }^{1} \mathrm{H}$ and ${ }^{13} \mathrm{C}$ NMR spectroscopy at variable temperature.

The two dimethyl complexes $\left[\mathrm{M}\left(\eta^{5}-\mathrm{C}_{5} \mathrm{H}_{5}\right)\left\{\eta^{5}\right.\right.$ $\left.\left.\mathrm{C}_{5} \mathrm{H}_{4} \mathrm{SiMe}_{2}\left(\mathrm{CH}_{2} \mathrm{CH}=\mathrm{CH}_{2}\right)\right\} \mathrm{Me}_{2}\right] \quad(\mathrm{M}=\mathrm{Ti} \quad \mathbf{1 6}, \mathrm{Zr} \quad \mathbf{1 8})$ react with $\mathrm{B}\left(\mathrm{C}_{6} \mathrm{~F}_{5}\right)_{3}$ to give products which do not show the typical NMR signals expected for the noncoordinated allyl group. Formation of the free borate anion $\left[\mathrm{MeB}\left(\mathrm{C}_{6} \mathrm{~F}_{5}\right)_{3}\right]^{-}$was detected by the presence of a broad singlet observed at $\sim \delta 0.39$ in the ${ }^{1} \mathrm{H}$ NMR spectra and the small $\Delta \delta(\delta \mathrm{m}-\delta \mathrm{p}) \approx 2 \mathrm{ppm}$ observed in the ${ }^{19} \mathrm{~F}$ spectra. Both features suggest that the reaction products should contain the double bond of the allyl moiety coordinated to the metal, although the 
complexity of the resulting mixture of products prevented their characterization. No reaction was observed when the dibenzyl titanium complex $\left[\mathrm{Ti}\left(\eta^{5}-\mathrm{C}_{5} \mathrm{H}_{5}\right)\left\{\eta^{5}\right.\right.$ $\left.\left.\mathrm{C}_{5} \mathrm{H}_{4} \mathrm{SiMe}_{2}\left(\mathrm{CH}_{2} \mathrm{CH}=\mathrm{CH}_{2}\right)\right\}\left(\mathrm{CH}_{2} \mathrm{Ph}\right)_{2}\right](\mathbf{2 0})$ was treated

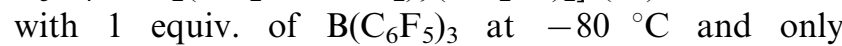
unidentified products resulted when the temperature was increased to $0{ }^{\circ} \mathrm{C}$, the transformation being irreversible.

We have shown above that the neutral dibenzyl indenyl zirconium complex $\left[\mathrm{Zr}\left(\eta^{5}-\mathrm{C}_{5} \mathrm{H}_{5}\right)\left\{\eta^{5}-\right.\right.$ $\left.\left.\mathrm{C}_{9} \mathrm{H}_{6} \mathrm{SiMe}_{2}\left(\mathrm{CH}_{2} \mathrm{CH}=\mathrm{CH}_{2}\right)\right\}\left(\mathrm{CH}_{2} \mathrm{Ph}\right)_{2}\right]$ (23) is a chiral molecule. The ${ }^{1} \mathrm{H}$ and ${ }^{13} \mathrm{C}$ NMR spectra recorded after mixing 1 equiv. of $\mathrm{B}\left(\mathrm{C}_{6} \mathrm{~F}_{5}\right)_{3}$ with 1 equiv of 23 in $\mathrm{CD}_{2} \mathrm{Cl}_{2}$ at $-80{ }^{\circ} \mathrm{C}$ showed the characteristic resonances of non-coordinated $\left[\left(\mathrm{CH}_{2} \mathrm{Ph}\right) \mathrm{B}\left(\mathrm{C}_{6} \mathrm{~F}_{5}\right)_{3}\right]^{-}(\delta$ 2.74) and demonstrated the formation of the cationic species $\left[\mathrm{Zr}\left(\eta^{5}-\mathrm{C}_{5} \mathrm{H}_{5}\right)\left\{\eta^{5}-\mathrm{C}_{9} \mathrm{H}_{6} \mathrm{SiMe}_{2}\left(\mathrm{CH}_{2} \mathrm{CH}=\mathrm{CH}_{2}\right)\right\}\right.$ $\left.\left(\mathrm{CH}_{2} \mathrm{Ph}\right)\right]^{+} 25$ (see Scheme 3). Assuming that at $80{ }^{\circ} \mathrm{C}$ alkene dissociation is fast and the two exo- and endo-isomers are in rapid equilibrium on the NMR time scale, the presence of two diastereomers would be expected as there are still two stereocentres: the metal and the enantioface of the 1-silyl-indenyl ligand. One diastereomer would locate the benzenic ring of the ligand eclipsed above the benzyl substituent, whereas in the other this ring would be staggered with respect to the benzyl substituent. The ${ }^{1} \mathrm{H}$ and ${ }^{13} \mathrm{C}$ NMR spectra of 25 at $-80{ }^{\circ} \mathrm{C}$ demonstrated that only one of the diastereomers was present, indicating that abstraction of benzyl by the boron Lewis acid is a highly selective reaction producing a unique diastereomer and maybe an undetectable amount of the second one. Appropriate NMR studies demonstrated that this single diastereomer corresponds to the conformation locating the benzyl substituent below the benzenic ring of the indenyl ligand. This is also consistent with the anisotropic displacement to highfield observed for one of the benzyl methylene $\left(\begin{array}{ll}\delta & 2.10\end{array}\right)$ and the olefinic $\mathrm{H}_{c i s}\left(\begin{array}{ll}\delta & 1.15\end{array}\right)$ protons. The signals of the two non-equivalent allylmethylenic protons in the cationic species are displaced to low field compared with the neutral compound (25: $\delta$ $2.29, \delta 2.54 ; 23: \delta$ 1.84), whereas the internal and the two non-equivalent external olefinic protons are displaced to low field (25: $\delta$ 7.43; 23: $\delta 5.75)$, and high field (25: $\delta 1.15, \delta$ 3.32; 23: $\delta$ 4.84), respectively. Similar behaviour was observed in the ${ }^{13} \mathrm{C}$ NMR spectra, the most remarkable change being the displacement to lower field observed for the internal olefinic carbon (25: $\delta$ 173.1; 23: $\delta$ 134.9). The same reversible dynamic behaviour described for $\mathbf{2 4}$ was also observed for $\mathbf{2 5}$ between -80 and $10{ }^{\circ} \mathrm{C}$. The benzyl-methylene resonances broaden between -80 and $-40{ }^{\circ} \mathrm{C}$ to give two broad signals at $-20{ }^{\circ} \mathrm{C}$ and the same behaviour was observed for the silyl-methyl, silyl-methylene and olefinic protons, indicating that they are associated with a unique dynamic process which involves alkene dissocia- tion combined with inversion at zirconium and recomplexation at the opposite side between the two enantiomers. The complexity of the broad and overlapped signals observed at temperatures higher than $20{ }^{\circ} \mathrm{C}$ and the appearance of new signals due to decomposition products before reaching the rapid equilibrium condition prevented the measurement of kinetic parameters.

The formation of these cationic species containing the allylic alkene moiety very weakly coordinated to the metal suggests that such species should behave as active catalysts for olefin polymerization. For this reason we used the zirconium dichloro complexes $\mathbf{1 2 - 1 4}$ as precursors for the generation of active Ziegler-type catalysts for exploring their ethylene polymerization activities. Compounds 12-14 were treated with 1000fold excess of MAO as activator at $21{ }^{\circ} \mathrm{C}$ under an atmosphere of ethylene for $30 \mathrm{~m}$. The activity found for the indenyl zirconium complex $14\left(1.04 \times 10^{6} \mathrm{~g}\right.$ PE $\mathrm{mol}^{-1} \mathrm{~h}^{-1} \mathrm{~atm}^{-1}$ ) is similar to that observed for the cyclopentadienyl derivative $13\left(1.30 \times 10^{6} \mathrm{~g} \mathrm{PE} \mathrm{mol}^{-1}\right.$ $\mathrm{h}^{-1} \mathrm{~atm}^{-1}$ ), although both complexes 13 and 14 bearing one allylsilyl-cyclopentadienyl and -indenyl ligand, respectively, were slightly better catalysts than complex $12\left(0.57 \times 10^{6} \mathrm{~g} \mathrm{PE} \mathrm{mol}^{-1} \mathrm{~h}^{-1} \mathrm{~atm}^{-1}\right)$ which contains two allylsilyl-substituted cyclopentadienyl rings. These small differences in activity are consistent with the comparable basicity and steric demands of the ligands attached to zirconium, in spite of the greater electron-donating ability of the indenyl compared with the cyclopentadienyl ligand [2c]. Polymerizations conducted over different time periods indicated that the activity decreases after $30 \mathrm{~m}$, although after $1.0 \mathrm{~h}$ an activity similar to that found for $\mathrm{ZrCp}_{2} \mathrm{Cl}_{2}$ was observed.

\section{Conclusions}

New dichloro metallocene-type Group 4 metal complexes containing silyl-substituted cyclopentadienyl ligands with a pendant allyl moiety have been successfully isolated and alkylated to give dimethyl and dibenzyl compounds. All have been thoroughly characterized by ${ }^{1} \mathrm{H}$ and ${ }^{13} \mathrm{C}$ NMR spectroscopy. The indenyl dibenzyl zirconium complex reacts with the Lewis acid $\mathrm{B}\left(\mathrm{C}_{6} \mathrm{~F}_{5}\right)_{3}$ at $-80{ }^{\circ} \mathrm{C}$ to generate one unique diastereomer of the mononuclear cationic species, which contains the allylic olefin coordinated to the metal. This asymmetric cation exhibits dynamic behaviour similar to that known for the cyclopentadienyl dibenzyl derivative, as monitored by ${ }^{1} \mathrm{H}$ and ${ }^{13} \mathrm{C}$ NMR spectroscopy between -80 and $10{ }^{\circ} \mathrm{C}$, although kinetic parameters could not be measured for this process. Similar methyl-olefin-coordinated cations were also formed for titanium and zirconium derivatives although the complex mixture of 
resulting products prevented their characterization. The dichloro zirconocene complexes were used as catalysts for ethylene polymerisation showing activities slightly higher than those known for $\mathrm{ZrCp}_{2} \mathrm{Cl}_{2}$.

\section{Experimental}

\subsection{General methods}

All manipulations were performed under an inert atmosphere of argon using standard Schlenck techniques or a M Braun dry box. Solvents used were previously dried and freshly distilled under argon: tetrahydrofuran from sodium benzophenone ketyl; $\mathrm{C}_{6} \mathrm{H}_{5} \mathrm{CH}_{3}$ from sodium; $\mathrm{C}_{6} \mathrm{H}_{14}$ from sodium-potassium amalgam. Deuterated solvents from Scharlau were degassed, dried and stored over molecular sieves. $\mathrm{ClSiMe}_{2}\left(\mathrm{CH}_{2}-\mathrm{CH}=\mathrm{CH}_{2}\right)$, TlOEt, BuLi, $\mathrm{ClSiMe}_{3}$, $\mathrm{TiCl}_{4}, \mathrm{MgClMe}$, and $\mathrm{MeLi}$ were obtained from commercial sources and used as received. $\left(\mathrm{C}_{5} \mathrm{H}_{5}\right) \mathrm{TiCl}_{3}$, $\left(\mathrm{C}_{5} \mathrm{Me}_{5}\right) \mathrm{TiCl}_{3}$ [11], [ $\left.\mathrm{Zr}\left(\eta^{5}-\mathrm{C}_{5} \mathrm{H}_{5}\right) \mathrm{Cl}_{3} \cdot \mathrm{DME}\right]$ [12] and $\mathrm{MgBz}_{2} \cdot 2 \mathrm{THF}$ [13] were isolated by reported methods.

${ }^{1} \mathrm{H}$ and ${ }^{13} \mathrm{C}$ NMR spectra were recorded on a Varian Unity VXR-300 or Varian Unity 500 Plus instruments. Chemical shifts, in $\mathrm{ppm}$, are measured relative to residual ${ }^{1} \mathrm{H}$ and ${ }^{13} \mathrm{C}$ resonances for $\mathrm{C}_{6} \mathrm{H}_{6}-\mathrm{d}_{6}$ used as solvent: $7.15\left({ }^{1} \mathrm{H}\right)$ and $128.0 \quad\left({ }^{13} \mathrm{C}\right)$, and coupling constants are in $\mathrm{Hz}$. Studies of cationic compounds were carried out in teflon valved NMR tubes in $\mathrm{CD}_{2} \mathrm{Cl}_{2}$. $\mathrm{C}, \mathrm{H}$ analyses were carried out with a Perkin-Elmer 240 $\mathrm{C}$ analyzer.

\subsection{Synthesis of $\mathrm{C}_{5} \mathrm{H}_{5} \mathrm{SiMe}_{2}\left(\mathrm{CH}_{2} \mathrm{CH}=\mathrm{CH}_{2}\right)$ (1)}

(Allyldimethyl)chlorosilane $(28.5 \mathrm{ml}, 25.39 \mathrm{~g}, 188$ mmol) was added to a suspension of $\mathrm{NaCp}(16.60 \mathrm{~g}$, $188 \mathrm{mmol})$ in $\mathrm{C}_{6} \mathrm{H}_{5} \mathrm{CH}_{3}(150 \mathrm{ml})$ cooled to $0{ }^{\circ} \mathrm{C}$. The suspension was warmed slowly to room temperature (r.t.) and stirred for $24 \mathrm{~h}$. Filtration and removal of the solvent at reduced pressure gave $\mathbf{1}$ as a pale yellow liquid. Yield: $21.86 \mathrm{~g}, 133 \mathrm{mmol}(86 \%) .{ }^{1} \mathrm{H}$ NMR (300 $\left.\mathrm{MHz}, \mathrm{C}_{6} \mathrm{D}_{6}, 25{ }^{\circ} \mathrm{C}\right): \delta-0.17$ (s, 6H, Si $\left.M_{2}\right), 1.40$ (d, $\left.2 \mathrm{H}, J_{\mathrm{H}-\mathrm{H}}=8.0 \mathrm{~Hz}, \mathrm{SiCH}_{2}\right), 3.29\left(\mathrm{~s}, 1 \mathrm{H}, \mathrm{C}_{5} H_{5}\right), 4.88$ $\left(2 \mathrm{~m}, 2 \mathrm{H},=\mathrm{CH}_{2}\right), 5.65(\mathrm{~m}, 1 \mathrm{H}, \mathrm{CH}=), 6.43,6.55(2 \mathrm{~m}$, $\left.4 \mathrm{H}, \mathrm{C}_{5} H_{5}\right) .{ }^{1} \mathrm{H}$ NMR $\left(300 \mathrm{MHz}, \mathrm{CDCl}_{3}, 25^{\circ} \mathrm{C}\right): \delta$ $-0.08\left(\mathrm{~s}, 6 \mathrm{H}, \mathrm{Si} M e_{2}\right), 1.55\left(\mathrm{~d}, 2 \mathrm{H}, J_{\mathrm{H}-\mathrm{H}}=8.0 \mathrm{~Hz}\right.$, $\left.\mathrm{SiCH}_{2}\right), 3.45\left(\mathrm{~s}, 1 \mathrm{H}, \mathrm{C}_{5} H_{5}\right), 4.85\left(\mathrm{~m}, 2 \mathrm{H},=\mathrm{CH}_{2}\right), 5.83$ $(\mathrm{m}, 1 \mathrm{H}, \mathrm{C} H=), 6.53,6.61\left(2 \mathrm{~m}, 4 \mathrm{H}, \mathrm{C}_{5} H_{5}\right)$.

\subsection{Synthesis of $\left[\mathrm{C}_{9} \mathrm{H}_{7}\left\{\mathrm{SiMe}_{2}\left(\mathrm{CH}_{2} \mathrm{CH}=\mathrm{CH}_{2}\right)\right\}\right]$ (2)}

(Allyldimethyl)chlorosilane $(13.5 \mathrm{ml}, 90 \mathrm{mmol})$ was added to a suspension of $\mathrm{LiC}_{9} \mathrm{H}_{7}(11.05 \mathrm{~g}, 90 \mathrm{mmol})$ in $\mathrm{C}_{6} \mathrm{H}_{5} \mathrm{CH}_{3}(100 \mathrm{ml})$. Following the same procedure described for $\mathbf{1}$ the (allyldimethyl)silylindene $\mathbf{2}$ was obtained as a yellow liquid. Yield: $13.17 \mathrm{~g}, 61 \mathrm{mmol}$, $69 \% .{ }^{1} \mathrm{H}$ NMR $\left(300 \mathrm{MHz}, \mathrm{C}_{6} \mathrm{D}_{6}, 25{ }^{\circ} \mathrm{C}\right): \delta-0.18$ (s, $\left.3 \mathrm{H}, \mathrm{Si} M e_{2}\right),-0.25\left(\mathrm{~s}, 3 \mathrm{H}, \mathrm{Si} M e_{2}\right), 1.36\left(\mathrm{~d}, 2 \mathrm{H}, J_{\mathrm{H}-\mathrm{H}}=\right.$ $\left.8.0 \mathrm{~Hz}, \mathrm{SiCH}_{2}\right), 3.35\left(\mathrm{~m}, 1 \mathrm{H}, H_{1}\right), 4.85,4.90(2 \mathrm{~m}, 2 \mathrm{H}$, = $\left.\mathrm{CH}_{2}\right), 5.59(\mathrm{~m}, 1 \mathrm{H}, \mathrm{CH}=), 6.45\left(\mathrm{dd}, 1 \mathrm{H}, J_{\mathrm{H}-\mathrm{H}}=5.5 \mathrm{~Hz}\right.$, $\left.J_{\mathrm{H}-\mathrm{H}}=1.8 \mathrm{~Hz}, H_{2}\right), 6.83\left(\mathrm{~m}, 1 \mathrm{H}, H_{3}\right), 7.19,7.41(\mathrm{~m}, 4 \mathrm{H}$, $\left.H_{4-7}\right) .{ }^{1} \mathrm{H}$ NMR $\left(300 \mathrm{MHz}, \mathrm{CDCl}_{3}, 25^{\circ} \mathrm{C}\right): \delta-0.02(\mathrm{~s}$, $\left.3 \mathrm{H}, \mathrm{Si} M e_{2}\right), 0.05\left(\mathrm{~s}, 3 \mathrm{H}, \mathrm{Si} M e_{2}\right), 1.61\left(\mathrm{dd}, 2 \mathrm{H}, J_{\mathrm{H}-\mathrm{H}}=\right.$ $\left.8.0 \mathrm{~Hz}, J_{\mathrm{H}-\mathrm{H}}=0.9 \mathrm{~Hz}, \mathrm{SiCH}_{2}\right), 3.67\left(\mathrm{~s}, 1 \mathrm{H}, H_{1}\right), 4.93$, $4.98\left(\mathrm{~m}, 2 \mathrm{H},=\mathrm{CH}_{2}\right), 5.80(\mathrm{~m}, 1 \mathrm{H}, \mathrm{CH}=), 6.74(\mathrm{dd}, 1 \mathrm{H}$, $\left.J_{\mathrm{H}-\mathrm{H}}=5.5 \mathrm{~Hz}, J_{\mathrm{H}-\mathrm{H}}=1.8 \mathrm{~Hz}, H_{2}\right), 7.01(\mathrm{dd}, 1 \mathrm{H}$, $\left.J_{\mathrm{H}-\mathrm{H}}=5.5 \mathrm{~Hz}, J_{\mathrm{H}-\mathrm{H}}=1.1 \mathrm{~Hz}, H_{3}\right), 7.55,7.29(\mathrm{~m}, 4 \mathrm{H}$, $\left.H_{4-7}\right)$.

\subsection{Synthesis of $\mathrm{Tl}\left[\mathrm{C}_{5} \mathrm{H}_{4}\left\{\mathrm{SiMe}_{2}\left(\mathrm{CH}_{2} \mathrm{CH}=\mathrm{CH}_{2}\right)\right\}\right]$ (5)}

A solution of TlOEt in $\mathrm{C}_{6} \mathrm{H}_{5} \mathrm{CH}_{3}(1.1 \mathrm{ml}, 15.2 \mathrm{mmol})$ was added to a solution of $\mathbf{1}(3.0 \mathrm{ml}, 15.2 \mathrm{mmol})$ in $\mathrm{Et}_{2} \mathrm{O}$ $(70 \mathrm{ml})$ at r.t. The solution was stirred for $12 \mathrm{~h}$. Removal of the solvent under vacuum yielded $\mathbf{5}$ as a white solid. Yield: $5.1 \mathrm{~g}, 13.8 \mathrm{mmol}, 92 \% .{ }^{1} \mathrm{H}$ NMR $(300 \mathrm{MHz}$, $\left.\mathrm{C}_{6} \mathrm{D}_{6}, 25{ }^{\circ} \mathrm{C}\right): \delta 0.25\left(\mathrm{~s}, 6 \mathrm{H}, \mathrm{Si}_{2}\right), 1.71(\mathrm{~d}, 2 \mathrm{H}$, $\left.J_{\mathrm{H}-\mathrm{H}}=8.0 \mathrm{~Hz}, \mathrm{SiCH}_{2}\right), 4.92\left(2 \mathrm{~m}, 2 \mathrm{H},=\mathrm{CH}_{2}\right), 5.90(\mathrm{~m}$, $1 \mathrm{H}, \mathrm{CH}=), 6.19\left(\mathrm{~m}, 2 \mathrm{H}, \mathrm{C}_{5} H_{4}\right), 6.26\left(\mathrm{~m}, 2 \mathrm{H}, \mathrm{C}_{5} H_{4}\right) ;{ }^{13} \mathrm{C}$ NMR $\left(300 \mathrm{MHz}, \mathrm{C}_{6} \mathrm{D}_{6}, 25{ }^{\circ} \mathrm{C}\right): \delta-0.8\left(\mathrm{Si}_{\mathrm{Me}}\right), 26.4$ $\left(\mathrm{SiCH}_{2}\right), 111.7\left(=\mathrm{CH}_{2}+C_{5} \mathrm{H}_{4}\right), 113.2\left(C_{5} \mathrm{H}_{4}\right), 114.9$ $\left(C_{5} \mathrm{H}_{4}\right), 136.5(\mathrm{CH}=)$. Anal. Found: C, 32.61; H, 4.09. Calc.: C, 32.67; H, 4.11\%.

\subsection{Synthesis of $\left[\mathrm{C}_{5} \mathrm{H}_{4}\left(\mathrm{SiMe}_{3}\right)\left\{\mathrm{SiMe}_{2}\left(\mathrm{CH}_{2} \mathrm{CH}=\right.\right.\right.$ $\left.\left.\left.\mathrm{CH}_{2}\right)\right\}\right]$ (6)}

A $1.6 \mathrm{M} \mathrm{C}_{6} \mathrm{H}_{5} \mathrm{CH}_{3}$ solution of n-butyllithium (7.52 $\mathrm{ml}, 12 \mathrm{mmol})$ was added to a solution of $\mathbf{1}(1.66 \mathrm{~g}, 12$ $\mathrm{mmol})$ in THF $(80 \mathrm{ml})$ at $-78{ }^{\circ} \mathrm{C}$. The mixture was allowed to warm to r.t. and stirred for an additional $3 \mathrm{~h}$ until gas evolution had completely ceased. $\mathrm{ClSiMe}_{3}$ $(1.83 \mathrm{ml}, 18 \mathrm{mmol})$ was added to the resulting solution containing the lithium salt 3 at $-78{ }^{\circ} \mathrm{C}$. The cooling bath was removed and the reaction mixture was stirred for $18 \mathrm{~h}$ at r.t. After removal of the solvent under vacuum the residue was extracted into $\mathrm{C}_{6} \mathrm{H}_{5} \mathrm{CH}_{3}(2 \times 75$ $\mathrm{ml}$ ), the solution was filtered and the solvent removed under vacuum to yield $\mathbf{6}$ as a light yellow liquid. Yield: $1.72 \mathrm{ml}, 7.32 \mathrm{mmol}, 61 \% .{ }^{1} \mathrm{H}$ NMR $\left(300 \mathrm{MHz}, \mathrm{C}_{6} \mathrm{D}_{6}\right.$, $\left.25{ }^{\circ} \mathrm{C}\right): \delta-0.06$ (s, 9H, SiMe $\left.e_{3}\right),-0.01$ (s, 6H, SiMe 2 ), $1.37\left(\mathrm{~d}, 2 \mathrm{H}, J_{\mathrm{H}-\mathrm{H}}=8.0 \mathrm{~Hz}, \mathrm{SiCH}_{2}\right), 4.90(\mathrm{~m}, 2 \mathrm{H},=$ $\left.\mathrm{CH}_{2}\right), 5.70(\mathrm{~m}, 1 \mathrm{H}, \mathrm{CH}=), 6.41\left(\mathrm{~m}, 2 \mathrm{H}, \mathrm{C}_{5} H_{4}\right), 6.71$ $\left(\mathrm{m}, 2 \mathrm{H}, \mathrm{C}_{5} \mathrm{H}_{4}\right)$.

\subsection{Synthesis of $\left[\mathrm{C}_{5} \mathrm{H}_{4}\left(\left\{\mathrm{SiMe}_{2}\left(\mathrm{CH}_{2} \mathrm{CH}=\mathrm{CH}_{2}\right)\right\}_{2}\right]\right.$ (7)}

The same procedure described to prepare 6 was followed using $\mathrm{ClSiMe}_{2}\left(\mathrm{CH}_{2}-\mathrm{CH}=\mathrm{CH}_{2}\right)$ instead of $\mathrm{ClSiMe}_{3} .{ }^{1} \mathrm{H}$ NMR $\left(300 \mathrm{MHz}, \mathrm{C}_{6} \mathrm{D}_{6}, 25{ }^{\circ} \mathrm{C}\right): \delta-0.02$ $(\mathrm{s}, 12 \mathrm{H}, \mathrm{SiMe} 2), 1.35\left(\mathrm{~d}, 4 \mathrm{H}, J_{\mathrm{H}-\mathrm{H}}=8.0 \mathrm{~Hz}, \mathrm{SiCH}_{2}\right)$, 
$4.91\left(2 \mathrm{~m}, 4 \mathrm{H},=\mathrm{CH}_{2}\right), 5.70(\mathrm{~m}, 2 \mathrm{H}, \mathrm{CH}=), 6.40(\mathrm{~m}, 2 \mathrm{H}$, $\left.\mathrm{C}_{5} H_{4}\right), 6.69\left(\mathrm{~m}, 2 \mathrm{H}, \mathrm{C}_{5} H_{4}\right)$.

\subsection{Synthesis of $\left[\mathrm{Ti}\left(\eta^{5}-\mathrm{C}_{5} \mathrm{H}_{4}\left\{\mathrm{SiMe}_{2}\left(\mathrm{CH}_{2} \mathrm{CH}=\right.\right.\right.\right.$ $\left.\left.\left.\mathrm{CH}_{2}\right)\right\} \mathrm{Cl}_{3}\right](\boldsymbol{8})$}

A solution of $\mathrm{TiCl}_{4}(0.97 \mathrm{~g}, 8.8 \mathrm{mmol})$ in $\mathrm{C}_{6} \mathrm{H}_{5} \mathrm{CH}_{3}$ (70 ml) was cooled to $0{ }^{\circ} \mathrm{C}$ and $7(2 \mathrm{ml}, 8.8 \mathrm{mmol})$ was added by syringe. The resulting orange solution became red after two days of reaction. After removal of the solvent under vacuum the residue was extracted into $\mathrm{C}_{5} \mathrm{H}_{12}(70 \mathrm{ml})$ and the solution was concentrated to 10 ml. Complex 8 was isolated by cooling its $\mathrm{C}_{6} \mathrm{H}_{14}$ solution to $-35{ }^{\circ} \mathrm{C}$ as a yellow crystalline solid which became a yellow oil at r.t. Yield: $1.76 \mathrm{~g}, 5.54 \mathrm{mmol}, 63 \%$. ${ }^{1} \mathrm{H}$ NMR $\left(300 \mathrm{MHz}, \mathrm{C}_{6} \mathrm{D}_{6}, 2{ }^{\circ} \mathrm{C}\right): \delta 0.17(\mathrm{~s}, 6 \mathrm{H}$, $\left.\mathrm{Si} M e_{2}\right), 1.51\left(\mathrm{~d}, 2 \mathrm{H}, J_{\mathrm{H}-\mathrm{H}}=8 \mathrm{~Hz}, \mathrm{SiCH}_{2}\right), 4.80(2 \mathrm{~m}, 2 \mathrm{H}$, $\left.=\mathrm{CH}_{2}\right), 5.53(\mathrm{~m}, 1 \mathrm{H}, \mathrm{CH}=), 6.18\left(\mathrm{~m}, 2 \mathrm{H}, \mathrm{C}_{5} H_{4}\right), 6.53$ $\left(\mathrm{m}, 2 \mathrm{H}, \mathrm{C}_{5} H_{4}\right) ;{ }^{13} \mathrm{C}$ NMR $\left(300 \mathrm{MHz}, \mathrm{C}_{6} \mathrm{D}_{6}, 25{ }^{\circ} \mathrm{C}\right): \delta$ -3.2 $(\mathrm{SiMe}), 23.7 \quad\left(\mathrm{SiCH} \mathrm{H}_{2}\right), 114.7 \quad\left(=\mathrm{CH}_{2}\right), 123.0$, $\left(C_{5} \mathrm{H}_{4}\right), 125.2\left(\mathrm{C}_{5} \mathrm{H}_{4}\right), 129.0\left(\mathrm{C}_{5} \mathrm{H}_{4}\right.$ ipso $), 139.5(\mathrm{CH}=)$. Anal. Found: C, 37.33; H, 4.46. Calc.: C, 37.82; H, $4.76 \%$

\subsection{Synthesis of [ $\mathrm{Ti}\left\{\eta^{5}-\mathrm{C}_{5} \mathrm{H}_{4}\left[\mathrm{SiMe}_{2}\left(\mathrm{CH}_{2} \mathrm{CH}=\right.\right.\right.$ $\left.\left.\left.\mathrm{CH}_{2}\right)\right]\right\}_{2} \mathrm{Cl}_{2}$ ] (9)}

A $\mathrm{C}_{6} \mathrm{H}_{5} \mathrm{CH}_{3}(40 \mathrm{ml})$ solution of $5(0.98 \mathrm{~g}, 2.76 \mathrm{mmol})$ was added to a $\mathrm{C}_{6} \mathrm{H}_{5} \mathrm{CH}_{3}(30 \mathrm{ml})$ solution of $8(0.85 \mathrm{ml}$, $2.76 \mathrm{mmol}$ ) at r.t. The starting yellow solution became red and the mixture was stirred for $6 \mathrm{~h}$ at $60{ }^{\circ} \mathrm{C}$. After filtration of the $\mathrm{TlCl}$, the solvent was concentrated to 10 $\mathrm{ml}$ and treated with $20 \mathrm{ml}$ of $\mathrm{C}_{6} \mathrm{H}_{5} \mathrm{CH}_{3}$. Complex 9 was isolated by cooling the solution to $-35{ }^{\circ} \mathrm{C}$ as a red microcrystalline solid. Yield: $0.8 \mathrm{~g}, 1.79 \mathrm{mmol}, 65 \% .{ }^{1} \mathrm{H}$ NMR (300 MHz, $\left.\mathrm{C}_{6} \mathrm{D}_{6}, 25{ }^{\circ} \mathrm{C}\right): \delta 0.39$ (s, 12H, SiMe $)$, $1.76\left(\mathrm{~d}, 4 \mathrm{H}, J_{\mathrm{H}-\mathrm{H}}=8.0 \mathrm{~Hz}, \mathrm{SiCH}_{2}\right), 4.80(2 \mathrm{~m}, 4 \mathrm{H},=$ $\left.\mathrm{CH}_{2}\right), 5.75(\mathrm{~m}, 2 \mathrm{H}, \mathrm{CH}=), 5.88\left(\mathrm{~m}, 4 \mathrm{H}, \mathrm{C}_{5} \mathrm{H}_{4}\right), 6.45(\mathrm{~m}$, $\left.4 \mathrm{H}, \mathrm{C}_{5} \mathrm{H}_{4}\right) ;{ }^{13} \mathrm{C}$ NMR $\left(300 \mathrm{MHz}, \mathrm{C}_{6} \mathrm{D}_{6}, 25{ }^{\circ} \mathrm{C}\right): \delta-2.2$ $\left(\mathrm{Si} M e_{2}\right), 24.9\left(\mathrm{SiCH}_{2}\right), 113.9\left(=\mathrm{CH}_{2}\right), 117.8\left(C_{5} \mathrm{H}_{4}\right)$, $130.2\left(C_{5} \mathrm{H}_{4}\right), 131.5\left(C_{5} \mathrm{H}_{4}\right.$ ipso $), 134.8(C \mathrm{H}=)$. Anal. Found: C, 54.22; H, 6.67. Calc.: C, 53.93; H, 6.79\%.

\subsection{Synthesis of $\left[\mathrm{Ti}\left(\eta^{5}-\mathrm{C}_{5} \mathrm{H}_{5}\right)\left(\eta^{5}-\mathrm{C}_{5} \mathrm{H}_{4}\left\{\mathrm{SiMe}_{2}\right.\right.\right.$} $\left.\left.\left.\left(\mathrm{CH}_{2} \mathrm{CH}=\mathrm{CH}_{2}\right)\right\}\right) \mathrm{Cl}_{2}\right](\mathbf{1 0})$

The same procedure described to prepare 9 was followed using $\mathrm{CpTiCl}_{3}(0.81 \mathrm{~g}, 3.65 \mathrm{mmol})$ instead of $\mathbf{8}$ to obtain $\mathbf{1 0}$ as a red microcrystaline solid. Yield: $0.9 \mathrm{~g}$, $2.59 \mathrm{mmol}, 70 \%$. ${ }^{1} \mathrm{H}$ NMR (300 MHz, $\left.\mathrm{C}_{6} \mathrm{D}_{6}, 25{ }^{\circ} \mathrm{C}\right): \delta$ $0.34\left(\mathrm{~s}, 6 \mathrm{H}, \mathrm{Si} M e_{2}\right), 1.71\left(\mathrm{~d}, 2 \mathrm{H}, J_{\mathrm{H}-\mathrm{H}}=8.0 \mathrm{~Hz}, \mathrm{SiCH}\right)_{2}$, $4.92\left(2 \mathrm{~m}, 2 \mathrm{H},=\mathrm{CH}_{2}\right), 5.72(\mathrm{~m}, 1 \mathrm{H}, \mathrm{CH}=), 5.82(\mathrm{~m}, 2 \mathrm{H}$, $\left.\mathrm{C}_{5} \mathrm{H}_{4}\right), 5.97\left(\mathrm{~s}, 5 \mathrm{H}, \mathrm{C}_{5} \mathrm{H}_{5}\right), 6.41\left(\mathrm{~m}, 2 \mathrm{H}, \mathrm{C}_{5} \mathrm{H}_{4}\right) ;{ }^{13} \mathrm{C}$ NMR (300 MHz, $\left.\mathrm{C}_{6} \mathrm{D}_{6}, 25{ }^{\circ} \mathrm{C}\right): \delta-2.1\left(\mathrm{SiMe}_{2}\right), 24.9$ $\left(\mathrm{SiCH}_{2}\right), 113.9\left(=\mathrm{CH}_{2}\right), 119.0\left(C_{5} \mathrm{H}_{4}\right), 119.7\left(C_{5} \mathrm{H}_{5}\right)$,
$129.5\left(C_{5} \mathrm{H}_{4}\right), 131.5\left(C_{5} \mathrm{H}_{4}\right.$ ipso $), 134.9(C \mathrm{H}=)$. Anal. Found: C, 51.63; H, 5.45. Calc.: C, 51.89; H, 5.81\%. 4.10. Synthesis of $\left[\mathrm{Ti}\left(\eta^{5}-\mathrm{C}_{5} \mathrm{Me}_{5}\right)\left(\eta^{5}-\mathrm{C}_{5} \mathrm{H}_{4}\left\{\mathrm{SiMe}_{2}\right.\right.\right.$
$\left.\left.\left.\left(\mathrm{CH}_{2} \mathrm{CH}=\mathrm{CH}_{2}\right)\right\}\right) \mathrm{Cl}_{2}\right](\mathbf{1 1})$

The same procedure described to prepare 9 was followed using $\mathrm{Cp}^{*} \mathrm{TiCl}_{3}(1.18 \mathrm{~g}, 4.08 \mathrm{mmol})$ instead of $\mathbf{8}$ to obtain $\mathbf{1 1}$ as a red microcrystalline solid. Yield: $1.17 \mathrm{~g}, 2.81 \mathrm{mmol}, 69 \%$. ${ }^{1} \mathrm{H}$ NMR $\left(300 \mathrm{MHz}, \mathrm{C}_{6} \mathrm{D}_{6}\right.$, $\left.25{ }^{\circ} \mathrm{C}\right): \delta 0.53\left(\mathrm{~s}, 6 \mathrm{H}, \mathrm{Si} M e_{2}\right), 1.71\left(\mathrm{~s}, 15 \mathrm{H}, \mathrm{C}_{5} M e_{5}\right)$, $1.89\left(\mathrm{~d}, 2 \mathrm{H}, J_{\mathrm{H}-\mathrm{H}}=8.0 \mathrm{~Hz}, \mathrm{SiCH}_{2}\right), 4.90,4.96(2 \mathrm{~m}, 2 \mathrm{H}$, $\left.=\mathrm{CH}_{2}\right), 5.59\left(\mathrm{~m}, 2 \mathrm{H}, \mathrm{C}_{5} H_{4}\right), 5.87(\mathrm{~m}, 1 \mathrm{H}, \mathrm{CH}=), 6.46$ $\left(\mathrm{m}, 2 \mathrm{H}, \mathrm{C}_{5} H_{4}\right) ;{ }^{13} \mathrm{C}$ NMR $\left(300 \mathrm{MHz}, \mathrm{C}_{6} \mathrm{D}_{6}, 25{ }^{\circ} \mathrm{C}\right): \delta$ -2.0 $\quad\left(\mathrm{SiMe}_{2}\right), \quad 13.5 \quad\left(\mathrm{C}_{5} \mathrm{Me}_{5}\right), \quad 25.2 \quad\left(\mathrm{SiCH}_{2}\right), \quad 113.5$ $\left(C_{5} \mathrm{H}_{4}\right), 115.6\left(=C \mathrm{H}_{2}\right), 129.1\left(C_{5} \mathrm{H}_{4}\right), 130.7\left(C_{5} \mathrm{Me}_{5}\right)$, $132.4\left(C_{5} \mathrm{H}_{4}\right.$ ipso $), 135.4(\mathrm{CH}=)$. Anal. Found: $\mathrm{C}, 57.70$; H, 7.14; Calc.: C, 57.56; H, 7.25\%.

\subsection{Synthesis of $\left[\mathrm{Zr}\left\{\eta^{5}-\mathrm{C}_{5} \mathrm{H}_{4}\left[\mathrm{SiMe}_{2}\left(\mathrm{CH}_{2} \mathrm{CH}=\right.\right.\right.\right.$ $\left.\left.\left.\left.\mathrm{CH}_{2}\right)\right]\right\}_{2} \mathrm{Cl}_{2}\right]($ (12)}

A $1.6 \mathrm{M} \mathrm{C}_{6} \mathrm{H}_{14}$ solution of n-butyllithium $(5.9 \mathrm{ml}$, $17.6 \mathrm{mmol})$ was added to a solution of 1 (3.54 g, 17.6 $\mathrm{mmol})$ in THF $(80 \mathrm{ml})$ at $-78{ }^{\circ} \mathrm{C}$. The mixture was allowed to warm to r.t. and stirred for additional $3 \mathrm{~h}$ until gas evolution had completely ceased. The resulting clear solution containing the lithium salt $\mathbf{3}$ was added dropwise to a $\mathrm{C}_{6} \mathrm{H}_{5} \mathrm{CH}_{3}(20 \mathrm{ml})$ suspension of $\mathrm{ZrCl}_{4}$ $(2.05 \mathrm{~g}, 8.81 \mathrm{mmol})$ at $-78{ }^{\circ} \mathrm{C}$. The mixture was allowed to warm to r.t. and stirred for additional $12 \mathrm{~h}$. After removal of the solvent under vacuum the residue was extracted into $\mathrm{C}_{6} \mathrm{H}_{5} \mathrm{CH}_{3}(60 \mathrm{ml})$ and the solution was concentrated to $10 \mathrm{ml}$ and treated with $\mathrm{C}_{6} \mathrm{H}_{14}(30$ $\mathrm{ml}$ ) to give $\mathbf{1 2}$ as a colourless crystalline solid, which was separated by filtration and dried under vacuum. Yield: $3.00 \mathrm{~g}, 6.13 \mathrm{mmol}, 69 \%$. ${ }^{1} \mathrm{H}$ NMR $\left(300 \mathrm{MHz}, \mathrm{C}_{6} \mathrm{D}_{6}\right.$, $\left.25{ }^{\circ} \mathrm{C}\right): \delta 0.37\left(\mathrm{~s}, 12 \mathrm{H}, \mathrm{Si} M e_{2}\right), 1.72\left(\mathrm{~d}, 4 \mathrm{H}, J_{\mathrm{H}-\mathrm{H}}=8.0\right.$ $\left.\mathrm{Hz}, \mathrm{SiCH}_{2}\right), 4.92\left(\mathrm{~m}, 4 \mathrm{H},=\mathrm{CH}_{2}\right), 5.69(\mathrm{~m}, 2 \mathrm{H}, \mathrm{CH}=)$, $5.90\left(\mathrm{~m}, 4 \mathrm{H}, \mathrm{C}_{5} H_{4}\right), 6.38\left(\mathrm{~m}, 4 \mathrm{H}, \mathrm{C}_{5} H_{4}\right) ;{ }^{13} \mathrm{C}$ NMR $(300$ $\left.\mathrm{MHz}, \mathrm{C}_{6} \mathrm{D}_{6}, 25{ }^{\circ} \mathrm{C}\right):-2.3\left(\mathrm{Si} M e_{2}\right), 24.8\left(\mathrm{SiCH}_{2}\right), 113.9$ $\left(=\mathrm{CH}_{2}\right), 115.1\left(C_{5} \mathrm{H}_{4}\right), 125.2\left(C_{5} \mathrm{H}_{4}\right.$ ipso $), 126.2\left(C_{5} \mathrm{H}_{4}\right)$, 134.6 $(\mathrm{CH}=)$. Anal. Found: $\mathrm{C}, 49.46 ; \mathrm{H}, 6.89$. Calc.: $\mathrm{C}$, $49.15 ; \mathrm{H}, 6.18 \%$.

4.12. Synthesis of $\left[\mathrm{Zr}\left(\eta^{5}-\mathrm{C}_{5} \mathrm{H}_{5}\right)\left\{\eta^{5}-\mathrm{C}_{5} \mathrm{H}_{4} \mathrm{SiMe}_{2}\right.\right.$

A THF $(20 \mathrm{ml})$ solution of $3(42.0 \mathrm{mmol})$ prepared as described for $\mathbf{1 2}$ was added dropwise to a suspension of $\left[\mathrm{Zr}\left(\eta^{5}-\mathrm{C}_{5} \mathrm{H}_{5}\right) \mathrm{Cl}_{3} \cdot \mathrm{DME}\right](14.9 \mathrm{~g}, 42.0 \mathrm{mmol})$ in THF (20 $\mathrm{ml})$ at $-78{ }^{\circ} \mathrm{C}$. The cooling bath was removed and the reaction mixture was stirred for $18 \mathrm{~h}$ at r.t. After removal of the solvent under vacuum the residue was extracted into $\mathrm{C}_{6} \mathrm{H}_{5} \mathrm{CH}_{3}(150 \mathrm{ml})$ and the solution was concentrated to $10 \mathrm{ml}$ and treated with $\mathrm{C}_{6} \mathrm{H}_{14}(80 \mathrm{ml})$ to 
give 13 as a colourless crystalline solid which was separated by filtration and dried under vacuum. Yield: $11.48 \mathrm{~g}, 37 \mathrm{mmol}, 88 \%$. ${ }^{1} \mathrm{H}$ NMR $\left(300 \mathrm{MHz}, \mathrm{C}_{6} \mathrm{D}_{6}\right.$, $\left.25{ }^{\circ} \mathrm{C}\right): \delta 0.35\left(\mathrm{~s}, 6 \mathrm{H}, \mathrm{Si} M e_{2}\right), 1.70\left(\mathrm{~d}, 2 \mathrm{H}, J_{\mathrm{H}-\mathrm{H}}=8.0\right.$ $\left.\mathrm{Hz}, \mathrm{SiCH}_{2}\right), 4.89\left(2 \mathrm{~m}, 2 \mathrm{H},=\mathrm{CH}_{2}\right), 5.71(\mathrm{~m}, 1 \mathrm{H}, \mathrm{CH}=)$, $5.86\left(\mathrm{~m}, 2 \mathrm{H}, \mathrm{C}_{5} H_{4}\right), 5.93\left(\mathrm{~s}, 5 \mathrm{H}, \mathrm{C}_{5} H_{5}\right), 6.33(\mathrm{~m}, 2 \mathrm{H}$, $\left.\mathrm{C}_{5} H_{4}\right) .{ }^{1} \mathrm{H}$ NMR $\left(300 \mathrm{MHz}, \mathrm{CDCl}_{3}, 25{ }^{\circ} \mathrm{C}\right): \delta 0.31(\mathrm{~s}$, $\left.6 \mathrm{H}, \mathrm{Si} M e_{2}\right), 1.71\left(\mathrm{~d}, 2 \mathrm{H}, J_{\mathrm{H}-\mathrm{H}}=8.0 \mathrm{~Hz}, \mathrm{SiCH}_{2}\right), 4.82$ $\left(\mathrm{m}, 2 \mathrm{H},=\mathrm{CH}_{2}\right), 5.69(\mathrm{~m}, 1 \mathrm{H}, \mathrm{CH}=), 6.52(\mathrm{~m}, 2 \mathrm{H}$, $\left.\mathrm{C}_{5} H_{4}\right), 6.44\left(\mathrm{~s}, 5 \mathrm{H}, \mathrm{C}_{5} H_{4}\right), 6.69\left(\mathrm{~m}, 2 \mathrm{H}, \mathrm{C}_{5} H_{4}\right) ;{ }^{13} \mathrm{C}$ NMR $\left(300 \mathrm{MHz}, \mathrm{C}_{6} \mathrm{D}_{6}, 25{ }^{\circ} \mathrm{C}\right): \delta-2.4\left(\mathrm{SiMe}_{2}\right), 24.9$ $\left(\mathrm{SiCH}_{2}\right), 113.9\left(=\mathrm{CH}_{2}\right), 115.7\left(C_{5} \mathrm{H}_{5}\right), 116.0\left(C_{5} \mathrm{H}_{4}\right)$, $116.3\left(C_{5} \mathrm{H}_{4}\right.$ ipso $), 125.5\left(C_{5} \mathrm{H}_{4}\right), 134.6(C \mathrm{H}=)$. Anal. Found: C, 45.66; H, 5.10. Calc.: C, 46.13; H, 5.16\%.

\subsection{Synthesis of $\left[\mathrm{Zr}\left(\eta^{5}-\mathrm{C}_{5} \mathrm{H}_{5}\right)\left\{\eta^{5}-\mathrm{C}_{9} \mathrm{H}_{6} \mathrm{SiMe}_{2}\right.\right.$ $\left.\left.\left(\mathrm{CH}_{2} \mathrm{CH}=\mathrm{CH}_{2}\right)\right\} \mathrm{Cl}_{2}\right]$ (14)}

The same procedure described to prepare $\mathbf{1 3}$ was followed using $2(7.62 \mathrm{~g}, 36.0 \mathrm{mmol})$, a $1.6 \mathrm{M} \mathrm{C}_{6} \mathrm{H}_{14}$ solution of n-buthyllithium $(22.5 \mathrm{ml}, 36.0 \mathrm{mmol})$ and $\left[\mathrm{Zr}\left(\eta^{5}-\mathrm{C}_{5} \mathrm{H}_{5}\right) \mathrm{Cl}_{3} \cdot \mathrm{DME}\right](12.3 \mathrm{~g}, 35 \mathrm{mmol})$ in THF $(100$ $\mathrm{ml}$ ) to obtain 14. Yield: $6.42 \mathrm{~g}, 14.6 \mathrm{mmol}, 42 \%$, as a yellow powder. ${ }^{1} \mathrm{H}$ NMR $\left(300 \mathrm{MHz}, \mathrm{C}_{6} \mathrm{D}_{6}, 25{ }^{\circ} \mathrm{C}\right) \delta$ 0.46 (s, 3H, SiMe $), 0.48$ (s, 3H, SiMe $), 1.83$ (2d, 2H, $\left.J_{\mathrm{H}-\mathrm{H}}=8.5 \mathrm{~Hz}, \mathrm{SiCH}_{2}\right), 4.87\left(2 \mathrm{~m}, 2 \mathrm{H},=\mathrm{CH}_{2}\right), 5.69(\mathrm{~m}$, $1 \mathrm{H}, \mathrm{CH}=), 5.72\left(\mathrm{~s}, 5 \mathrm{H}, \mathrm{C}_{5} H_{5}\right), 6.28\left(\mathrm{~d}, J_{\mathrm{H}-\mathrm{H}}=5.5 \mathrm{~Hz}\right.$, $\left.1 \mathrm{H}, H_{2}\right), 6.72\left(\mathrm{~m}, 1 \mathrm{H}, H_{3}\right), 6.82,6.93,7.22,7.65(\mathrm{~m}, 4 \mathrm{H}$, $\left.H_{4-7}\right) .{ }^{1} \mathrm{H}$ NMR $\left(300 \mathrm{MHz}, \mathrm{CDCl}_{3}, 25{ }^{\circ} \mathrm{C}\right): \delta 0.43(\mathrm{~s}$, $\left.3 \mathrm{H}, \mathrm{Si} M e_{2}\right), 0.47\left(\mathrm{~s}, 3 \mathrm{H}, \mathrm{Si} M e_{2}\right), 1.82\left(2 \mathrm{~d}, 2 \mathrm{H}, J_{\mathrm{H}-\mathrm{H}}=\right.$ $\left.8.0 \mathrm{~Hz}, \mathrm{SiCH}_{2}\right), 4.82\left(2 \mathrm{~m}, 2 \mathrm{H},=\mathrm{CH}_{2}\right), 5.69(\mathrm{~m}, 1 \mathrm{H}$, $\mathrm{CH}=), 6.06\left(\mathrm{~s}, 5 \mathrm{H}, \mathrm{C}_{5} H_{5}\right), 6.83\left(\mathrm{~d}, 1 \mathrm{H}, J_{\mathrm{H}-\mathrm{H}}=2.9 \mathrm{~Hz}\right.$, $\left.H_{2}\right), 7.00\left(\mathrm{~d}, 1 \mathrm{H}, J_{\mathrm{H}-\mathrm{H}}=3.3 \mathrm{~Hz}, H_{3}\right), 7.31,7.68,7.82(\mathrm{~m}$, $\left.4 \mathrm{H}, H_{4-7}\right) ;{ }^{13} \mathrm{C}$ NMR $\left(300 \mathrm{MHz}, \mathrm{C}_{6} \mathrm{D}_{6}, 25{ }^{\circ} \mathrm{C}\right) \delta-2.2$ $\left(\mathrm{Si} M e_{2}\right),-1.7\left(\mathrm{SiMe} e_{2}\right), 24.8\left(\mathrm{SiCH}_{2}\right), 114.0\left(=\mathrm{CH}_{2}\right)$, $116.5\left(C_{5} \mathrm{H}_{5}\right), 108.3,111.2,125.6,125.7,125.9,126.9$, 127.3, 132.0, $133.5\left(C_{9} \mathrm{H}_{6}\right), 134.6(C \mathrm{H}=)$. Anal. Found: C, 52.12; H, 5.09. Calc.: C, 51.80; H, 5.03\%.

\subsection{Synthesis of $\left[\mathrm{Ti}\left(\eta^{5}-\mathrm{C}_{5} \mathrm{H}_{5}\right)\left\{\eta^{5}-\mathrm{C}_{5} \mathrm{H}_{4} \mathrm{SiMe}_{2}\right.\right.$ $\left.\left.\left(\mathrm{CH}_{2} \mathrm{CH}=\mathrm{CH}_{2}\right)\right\} \mathrm{ClMe}\right](15)$}

A $3 \mathrm{M}$ THF solution of $\mathrm{MgClMe}(0.48 \mathrm{ml}, 1.44$ mmol) was added at $-78{ }^{\circ} \mathrm{C}$ to a solution of $\mathbf{1 0}(0.5 \mathrm{~g}$, $1.44 \mathrm{mmol})$ in $\mathrm{C}_{6} \mathrm{H}_{14}(50 \mathrm{ml})$. The reaction mixture was stirred for $2 \mathrm{~h}$ while it was warmed slowly to r.t. The orange solution was filtered and the solution concentrated to $15 \mathrm{ml}$ under vacuum and cooled to $-35{ }^{\circ} \mathrm{C}$. After filtration complex $\mathbf{1 5}$ was collected as a red orange crystalline solid and dried under vacuum. Yield: $0.32 \mathrm{~g}$, $1.0 \mathrm{mmol}, 70 \%$. ${ }^{1} \mathrm{H}$ NMR $\left(300 \mathrm{MHz}, \mathrm{C}_{6} \mathrm{D}_{6}, 25{ }^{\circ} \mathrm{C}\right): \delta$ 0.18 (s, 3H, Si Me 2 ), 0.29 (s, 3H, SiMe $), 0.87$ (s, 3H, TiMe $), 1.67\left(2 \mathrm{~d}, 2 \mathrm{H}, J_{\mathrm{H}-\mathrm{H}}=8.0 \mathrm{~Hz}, \mathrm{SiCH}_{2}\right), 4.92(2 \mathrm{~m}$, $\left.2 \mathrm{H},=\mathrm{CH}_{2}\right), 5.75(\mathrm{~m}, 1 \mathrm{H}, \mathrm{CH}=), 5.80\left(\mathrm{~s}, 5 \mathrm{H}, \mathrm{C}_{5} H_{5}\right), 5.05$ $\left(\mathrm{m}, 1 \mathrm{H}, \mathrm{C}_{5} H_{4}\right), 5.51\left(\mathrm{~m}, 1 \mathrm{H}, \mathrm{C}_{5} H_{4}\right), 6.29\left(\mathrm{~m}, 1 \mathrm{H}, \mathrm{C}_{5} H_{4}\right)$, $6.77\left(\mathrm{~m}, 1 \mathrm{H}, \mathrm{C}_{5} H_{4}\right) ;{ }^{13} \mathrm{C} \mathrm{NMR}\left(300 \mathrm{MHz}, \mathrm{C}_{6} \mathrm{D}_{6}\right.$, $\left.25{ }^{\circ} \mathrm{C}\right): \delta-2.5(\mathrm{SiMe}),-2.4(\mathrm{SiMe}), 24.9\left(\mathrm{SiCH}_{2}\right)$, $49.0(\mathrm{TiMe}), 113.2\left(C_{5} \mathrm{H}_{4}\right), 113.8\left(=\mathrm{CH}_{2}\right), 115.9\left(C_{5} \mathrm{H}_{5}\right)$, $117.6\left(C_{5} \mathrm{H}_{4}\right), 123.2\left(\mathrm{C}_{5} \mathrm{H}_{4}\right), 127.0\left(\mathrm{C}_{5} \mathrm{H}_{4}\right.$ ipso $), 134.8$ $(\mathrm{CH}=)$. Anal. Found: C, 58.42; H, 7.13. Calc.: C, 58.81; $\mathrm{H}, 7.09 \%$.

\subsection{Synthesis of $\left[\mathrm{Ti}\left(\eta^{5}-\mathrm{C}_{5} \mathrm{H}_{5}\right)\left(\eta^{5}-\mathrm{C}_{5} \mathrm{H}_{4}\left\{\mathrm{SiMe}_{2}\right.\right.\right.$ $\left.\left.\left(\mathrm{CH}_{2} \mathrm{CH}=\mathrm{CH}_{2}\right)\right\} \mathrm{Me}_{2}\right]$ (16)}

A $3 \mathrm{M}$ THF solution of $\mathrm{MgClMe}(0.77 \mathrm{ml}, 2.30$ mmol) was added at $-78{ }^{\circ} \mathrm{C}$ to a solution of $10(0.40 \mathrm{~g}$, $1.15 \mathrm{mmol})$ in $\mathrm{C}_{6} \mathrm{H}_{14}(50 \mathrm{ml})$. The reaction mixture was stirred for $2 \mathrm{~h}$ while it was warmed slowly to r.t. The orange solution formed was filtered and after removal of the solvent under vacuum complex $\mathbf{1 6}$ was collected as an orange oil and dried under vacuum. Yield: $0.23 \mathrm{~g}$, $0.74 \mathrm{mmol}, 65 \% .{ }^{1} \mathrm{H}$ NMR $\left(300 \mathrm{MHz}, \mathrm{C}_{6} \mathrm{D}_{6}, 2{ }^{\circ} \mathrm{C}\right): \delta$ 0.05 (s, 6H, $\left.\mathrm{SiMe}_{2}\right), 0.10$ (s, 6H, TiMe $), 1.55$ (d, 2H, $\left.J_{\mathrm{H}-\mathrm{H}}=8.0 \mathrm{~Hz}, \mathrm{SiCH}_{2}\right), 4.90\left(2 \mathrm{~m}, 2 \mathrm{H},=\mathrm{CH}_{2}\right), 5.76(\mathrm{~s}$, $\left.5 \mathrm{H}, \mathrm{C}_{5} \mathrm{H}_{5}\right), 5.75(\mathrm{~m}, 1 \mathrm{H}, \mathrm{CH}=), 5.91\left(\mathrm{~m}, 2 \mathrm{H}, \mathrm{C}_{5} \mathrm{H}_{4}\right), 5.97$ $\left(\mathrm{m}, 2 \mathrm{H}, \mathrm{C}_{5} \mathrm{H}_{4}\right) ;{ }^{13} \mathrm{C}$ NMR $\left(300 \mathrm{MHz}, \mathrm{C}_{6} \mathrm{D}_{6}, 25{ }^{\circ} \mathrm{C}\right): \delta$ -2.6 $\left(\mathrm{SiMe}_{2}\right), 25.2\left(\mathrm{TiMe}_{2}\right), 46.6\left(\mathrm{SiCH}_{2}\right), 113.7\left(\mathrm{C}_{5} \mathrm{H}_{5}\right)$, $115.8\left(\mathrm{C}_{5} \mathrm{H}_{4}\right), 117.4\left(=\mathrm{CH}_{2}\right), 118.8\left(C_{5} \mathrm{H}_{4}\right), 120.2\left(C_{5} \mathrm{H}_{4}\right.$ ipso $), 134.8(\mathrm{CH}=)$. Anal. Found: $\mathrm{C}, 66.45 ; \mathrm{H}, 8.67$. Calc.: C, $66.65 ; \mathrm{H}, 8.55 \%$.

\subsection{Synthesis of $\left[\mathrm{Zr}\left\{\eta^{5}-\mathrm{C}_{5} \mathrm{H}_{4}\left[\mathrm{SiMe}_{2}\left(\mathrm{CH}_{2} \mathrm{CH}=\right.\right.\right.\right.$ $\left.\left.\mathrm{CH}_{2}\right)\right\}_{2} \mathrm{Me}_{2}$ ] (17)}

The same procedure described to prepare $\mathbf{1 6}$ was followed using a $1.6 \mathrm{M} \mathrm{Et}_{2} \mathrm{O}$ solution of methyllithium $(2.1 \mathrm{ml}, 3.4 \mathrm{mmol})$ and $12(0.74 \mathrm{~g}, 1.51 \mathrm{mmol})$ in $\mathrm{Et}_{2} \mathrm{O}$ $(40 \mathrm{ml})$ to give $\mathbf{1 7}$ as a brown oil which could not be crystallized. Yield: $0.45 \mathrm{~g}, 1.0 \mathrm{mmol}, 67 \% .{ }^{1} \mathrm{H}$ NMR $\left(300 \mathrm{MHz}, \mathrm{C}_{6} \mathrm{D}_{6}, 25{ }^{\circ} \mathrm{C}\right): \delta-0.07$ (s, $\left.6 \mathrm{H}, \mathrm{Zr} \mathrm{Me}_{2}\right), 0.19$ (s, $\left.12 \mathrm{H}, \mathrm{Si} M e_{2}\right), 1.36\left(\mathrm{~d}, 4 \mathrm{H}, J_{\mathrm{H}-\mathrm{H}}=8.0 \mathrm{~Hz}, \mathrm{SiCH}_{2}\right)$, $4.94\left(\mathrm{~m}, 4 \mathrm{H},=\mathrm{CH}_{2}\right), 5.75(\mathrm{~m}, 2 \mathrm{H}, \mathrm{CH}=), 5.91(\mathrm{~m}, 4 \mathrm{H}$, $\left.\mathrm{C}_{5} \mathrm{H}_{4}\right), 6.08\left(\mathrm{~m}, 4 \mathrm{H}, \mathrm{C}_{5} \mathrm{H}_{4}\right) ;{ }^{13} \mathrm{C} \mathrm{NMR}\left(300 \mathrm{MHz}, \mathrm{C}_{6} \mathrm{D}_{6}\right.$, $\left.25^{\circ} \mathrm{C}\right): \delta-2.4\left(\mathrm{SiMe}_{2}\right), 25.3\left(\mathrm{SiCH}_{2}\right), 31.0(\mathrm{ZrMe})$, $113.4\left(=\mathrm{CH}_{2}\right), 113.7\left(C_{5} \mathrm{H}_{4}\right), 117.8\left(C_{5} \mathrm{H}_{4}\right.$ ipso $), 118.2$ $\left(C_{5} \mathrm{H}_{4}\right), 134.7(C \mathrm{H}=)$. Anal. Found: $\mathrm{C}, 58.94 ; \mathrm{H}, 8.01$. Calc.: C, $59.03 ; \mathrm{H}, 8.04 \%$.

\subsection{Synthesis of $\left[\mathrm{Zr}\left(\eta^{5}-\mathrm{C}_{5} \mathrm{H}_{5}\right)\left(\eta^{5}-\mathrm{C}_{5} \mathrm{H}_{4}\left\{\mathrm{SiMe}_{2}\right.\right.\right.$ $\left.\left.\left(\mathrm{CH}_{2} \mathrm{CH}=\mathrm{CH}_{2}\right)\right\} \mathrm{Me}_{2}\right]$ (18)}

A $1.6 \mathrm{M} \mathrm{Et}_{2} \mathrm{O}$ solution of methyllithium $(1.0 \mathrm{ml}, 1.6$ mmol) was added at $-78{ }^{\circ} \mathrm{C}$ to a solution of $13(0.55 \mathrm{~g}$, $1.42 \mathrm{mmol})$ in $\mathrm{Et}_{2} \mathrm{O}(30 \mathrm{ml})$. The reaction mixture was stirred for $18 \mathrm{~h}$ while it was warmed slowly to r.t. The $\mathrm{Et}_{2} \mathrm{O}$ was removed under vacuum and the residue was extracted into $\mathrm{C}_{6} \mathrm{H}_{14}(30 \mathrm{ml})$. After removal of the $\mathrm{C}_{6} \mathrm{H}_{14}$ at reduced pressure the residue was washed with cold $\mathrm{C}_{6} \mathrm{H}_{14}\left(-78{ }^{\circ} \mathrm{C}\right)$ and complex $18(0.43 \mathrm{~g}, 87 \%)$ was obtained as a colourless waxy oil which could not be 
crystallized. ${ }^{1} \mathrm{H}$ NMR $\left(300 \mathrm{MHz}, \mathrm{C}_{6} \mathrm{D}_{6}, 25{ }^{\circ} \mathrm{C}\right): \delta$ -0.11 (s, 6H, ZrMe $), 0.14$ (s, 6H, SiMe $), 1.58$ (d, 2H, $\left.J_{\mathrm{H}-\mathrm{H}}=8.0 \mathrm{~Hz}, \mathrm{SiCH}_{2}\right), 4.89\left(2 \mathrm{~m}, 2 \mathrm{H},=\mathrm{CH}_{2}\right), 5.71(\mathrm{~m}$, $1 \mathrm{H}, \mathrm{CH}=), 5.78\left(\mathrm{~s}, 5 \mathrm{H}, \mathrm{C}_{5} H_{5}\right), 5.90\left(\mathrm{~m}, \mathrm{C}_{5} H_{4}\right), 5.95(\mathrm{~m}$, $\left.2 \mathrm{H}, \mathrm{C}_{5} H_{4}\right) ;{ }^{13} \mathrm{C}$ NMR $\left(300 \mathrm{MHz}, \mathrm{C}_{6} \mathrm{D}_{6}, 25{ }^{\circ} \mathrm{C}\right): \delta-2.4$ $(\mathrm{SiMe}), 25.3\left(\mathrm{SiCH}_{2}\right), 30.8(\mathrm{ZrMe}), 110.6\left(\mathrm{C}_{5} \mathrm{H}_{5}\right)$, $113.8 \quad\left(=\mathrm{CH}_{2}\right), \quad 114.2 \quad\left(\mathrm{C}_{5} \mathrm{H}_{4}\right), \quad 117.4 \quad\left(\mathrm{C}_{5} \mathrm{H}_{4}\right), \quad 118.4$ $\left(\mathrm{C}_{5} \mathrm{H}_{4}\right.$ ipso $), 134.8(\mathrm{CH}=)$. Anal. Found: $\mathrm{C}, 58.23 ; \mathrm{H}$, 7.46. Calc.: C, 58.39; H, 7.49\%.

\subsection{Synthesis of $\left[\mathrm{Zr}\left(\eta^{5}-\mathrm{C}_{5} \mathrm{H}_{5}\right)\left\{\eta^{5}-\mathrm{C}_{9} \mathrm{H}_{6} \mathrm{SiMe}_{2}\right.\right.$ $\left.\left.\left(\mathrm{CH}_{2} \mathrm{CH}=\mathrm{CH}_{2}\right)\right\} \mathrm{Me}_{2}\right]$ (19)}

The same procedure described to prepare $\mathbf{1 6}$ was followed using $14(1.576 \mathrm{~g}, 3.58 \mathrm{mmol})$ and a $1.6 \mathrm{M}$ $\mathrm{Et}_{2} \mathrm{O}$ solution of methyllithium $(4.5 \mathrm{ml}, 7.2 \mathrm{mmol})$ in $\mathrm{Et}_{2} \mathrm{O}(60 \mathrm{ml})$ to give 19 as a yellow oil. Yield: $0.77 \mathrm{~g}, 1.93$ mmol, 54\%. ${ }^{1} \mathrm{H}$ NMR $\left(300 \mathrm{MHz}, \mathrm{C}_{6} \mathrm{D}_{6}, 25{ }^{\circ} \mathrm{C}\right): \delta$ -0.35 (s, 3H, ZrMe $),-0.29$ (s, 3H, ZrMe $), 0.24$ (s, $\left.3 \mathrm{H}, \mathrm{Si} M e_{2}\right), 0.29$ (s, 3H, SiMe $), 1.70\left(2 \mathrm{~d}, 2 \mathrm{H}, J_{\mathrm{H}-\mathrm{H}}=\right.$ $\left.8.1 \mathrm{~Hz}, \mathrm{SiCH}_{2}\right), 4.90\left(2 \mathrm{~m}, 2 \mathrm{H},=\mathrm{CH}_{2}\right), 5.56(\mathrm{~s}, 5 \mathrm{H}$, $\left.\mathrm{C}_{5} H_{5}\right), 5.70(\mathrm{~m}, 1 \mathrm{H}, \mathrm{CH}=), 6.29\left(\mathrm{~d}, 1 \mathrm{H}, J_{\mathrm{H}-\mathrm{H}}=3.3 \mathrm{~Hz}\right.$, $\left.H_{2}\right), 6.41\left(\mathrm{dd}, 1 \mathrm{H}, J_{\mathrm{H}-\mathrm{H}}=3.3 \mathrm{~Hz}, J_{\mathrm{H}-\mathrm{H}}=0.7 \mathrm{~Hz}, H_{3}\right)$, $6.89\left(\mathrm{~m}, 2 \mathrm{H}, H_{4-7}\right), 7.30\left(\mathrm{~m}, 1 \mathrm{H}, H_{4-7}\right), 7.44(\mathrm{~m}, 1 \mathrm{H}$, $\left.H_{4-7}\right) ;{ }^{13} \mathrm{C}$ NMR $\left(300 \mathrm{MHz}, \quad \mathrm{C}_{6} \mathrm{D}_{6}, \quad 25{ }^{\circ} \mathrm{C}\right): \quad \delta$ -1.1 $\left.\left.(\mathrm{SiMe})_{2}\right),-1.0(\mathrm{SiMe})_{2}\right), 25.1\left(\mathrm{SiCH}_{2}\right), 33.0,33.8$ $(\mathrm{ZrMe}), 113.8\left(=\mathrm{CH}_{2}\right), 123.6\left(\mathrm{C}_{5} \mathrm{H}_{5}\right), 107.2,110.3$, 111.6, 124.0, 125.1, 125.3, 126.6, 129.4, $135.7\left(C_{9} \mathrm{H}_{6}\right)$, $134.4(\mathrm{CH}=)$. Anal. Found: C, 63.07; H, 6.71. Calc.: C, $63.10 ; \mathrm{H}, 7.06 \%$.

4.19. Synthesis of $\left[\mathrm{Ti}\left(\eta^{5}-\mathrm{C}_{5} \mathrm{H}_{5}\right)\left(\eta^{5}-\mathrm{C}_{5} \mathrm{H}_{4}\left\{\mathrm{SiMe}_{2}\right.\right.\right.$ $\left.\left.\left(\mathrm{CH}_{2} \mathrm{CH}=\mathrm{CH}_{2}\right)\right\}\left(\mathrm{CH}_{2} \mathrm{Ph}\right)_{2}\right](2 \mathrm{O})$

Hexane $(50 \mathrm{ml})$ cooled to $-78{ }^{\circ} \mathrm{C}$ was added to a mixture of $\mathrm{MgBz}_{2} \cdot 2 \mathrm{THF}(0.46 \mathrm{~g}, 1.29 \mathrm{mmol})$ and $\mathbf{1 0}$ $(0.45 \mathrm{~g}, 1.29 \mathrm{mmol})$. The suspension was stirred for $2 \mathrm{~h}$ while warming slowly to r.t. After filtration, the solution was concentrated to $5 \mathrm{ml}$ and cooled to $-35{ }^{\circ} \mathrm{C}$. Complex 20 was collected as a dark red solid and dried under vacuum. Yield: $0.46 \mathrm{~g}, 1.02 \mathrm{mmol}, 79 \% .{ }^{1} \mathrm{H}$ NMR $\left(300 \mathrm{MHz}, \mathrm{C}_{6} \mathrm{D}_{6}, 25{ }^{\circ} \mathrm{C}\right): \delta-0.05$ (s, 6H, SiMe $), 1.45$ (d, $\left.2 \mathrm{H}, \mathrm{SiCH}_{2}\right), 1.83\left(\mathrm{~d}, 2 \mathrm{H}, \mathrm{CH}_{2} \mathrm{Ph}\right), 2.11(\mathrm{~d}, 2 \mathrm{H}$, $\left.\mathrm{CH}_{2} \mathrm{Ph}\right), 4.87\left(2 \mathrm{~m}, 2 \mathrm{H},=\mathrm{CH}_{2}\right), 5.65(\mathrm{~m}, 1 \mathrm{H}, \mathrm{CH}=), 5.71$ $\left(\mathrm{s}, 5 \mathrm{H}, \mathrm{C}_{5} H_{5}\right), 5.87\left(\mathrm{~m}, 2 \mathrm{H}, \mathrm{C}_{5} H_{4}\right), 6.11\left(\mathrm{~m}, 2 \mathrm{H}, \mathrm{C}_{5} H_{4}\right)$, $\left.6.85\left(\mathrm{~m}, 4 \mathrm{H}, \mathrm{C}_{6} H_{5}\right), 6.93 \mathrm{~m}, 2 \mathrm{H}, \mathrm{C}_{6} H_{5}\right), 7.21(\mathrm{~m}, 4 \mathrm{H}$, $\left.\mathrm{C}_{6} H_{5}\right) ;{ }^{13} \mathrm{C}$ NMR $\left(300 \mathrm{MHz}, \mathrm{C}_{6} \mathrm{D}_{6}, 25{ }^{\circ} \mathrm{C}\right): \delta-2.7$ $\left(\mathrm{SiMe}_{2}\right), 24.9\left(\mathrm{SiCH}_{2}\right), 74.4\left(\mathrm{CH}_{2} \mathrm{Ph}\right), 114.0\left(=\mathrm{CH}_{2}\right)$, $115.7\left(C_{5} \mathrm{H}_{5}\right), 119.7\left(C_{5} \mathrm{H}_{4}\right), 122.0\left(C_{6} \mathrm{H}_{5}\right), 123.6\left(C_{5} \mathrm{H}_{4}\right.$ ipso $), 126.3\left(C_{6} \mathrm{H}_{5}\right), 128.3\left(C_{6} \mathrm{H}_{5}\right), 129.3\left(C_{5} \mathrm{H}_{4}\right), 134.3$ $(C \mathrm{H}=), 154.2\left(C_{6} \mathrm{H}_{5}\right)$. Anal. Found: $\mathrm{C}, 75.15 ; \mathrm{H}, 7.32$. Calc.: C, 75.96; H, 7.47\%.
4.20. Synthesis of $\left[\mathrm{Zr}\left\{\eta^{5}-\mathrm{C}_{5} \mathrm{H}_{4}\left[\mathrm{SiMe}_{2}\left(\mathrm{CH}_{2} \mathrm{CH}=\right.\right.\right.\right.$ $\left.\left.\left.\mathrm{CH}_{2}\right)_{3}\right\}_{2}\left(\mathrm{CH}_{2} \mathrm{Ph}\right)_{2}\right](21)$

The same procedure described to prepare 19 was followed using $\mathrm{Mg}\left(\mathrm{CH}_{2} \mathrm{Ph}\right)_{2} \cdot 2 \mathrm{THF}(0.71 \mathrm{~g}, 2.05 \mathrm{mmol})$ and $\mathbf{1 2}$ in $\mathrm{Et}_{2} \mathrm{O}(70 \mathrm{ml})$ to give $\mathbf{2 1}$ as a yellow orange oil. Yield: $0.84 \mathrm{~g}, 1.39 \mathrm{mmol}, 70 \%$. ${ }^{1} \mathrm{H}$ NMR $(300 \mathrm{MHz}$, $\left.\mathrm{C}_{6} \mathrm{D}_{6}, 25{ }^{\circ} \mathrm{C}\right): \delta 0.17\left(\mathrm{~s}, 12 \mathrm{H}, \mathrm{Si} M e_{2}\right), 1.57(\mathrm{~d}, 4 \mathrm{H}$, $\left.J_{\mathrm{H}-\mathrm{H}}=8.4 \mathrm{~Hz}, \mathrm{SiCH}_{2}\right), 1.83\left(\mathrm{~m}, 4 \mathrm{H}, \mathrm{CH}_{2} \mathrm{Ph}\right), 4.84(\mathrm{~m}$, $\left.4 \mathrm{H},=\mathrm{CH}_{2}\right), 5.65(\mathrm{~m}, 2 \mathrm{H}, \mathrm{CH}=), 5.95\left(\mathrm{~m}, 4 \mathrm{H}, \mathrm{C}_{5} H_{4}\right)$, $6.15\left(\mathrm{~m}, 4 \mathrm{H}, \mathrm{C}_{5} H_{4}\right), 6.80\left(\mathrm{~m}, 6 \mathrm{H}, p-\right.$ and $\left.o-\mathrm{C}_{6} H_{5}\right), 7.16$ $\left(\mathrm{m}, 4 \mathrm{H}, m-\mathrm{C}_{6} H_{5}\right) ;{ }^{13} \mathrm{C} \mathrm{NMR}\left(300 \mathrm{MHz}, \mathrm{C}_{6} \mathrm{D}_{6}, 25{ }^{\circ} \mathrm{C}\right)$ : $\delta-2.4\left(\mathrm{SiMe}_{2}\right), 25.2\left(\mathrm{SiCH}_{2}\right), 61.5\left(\mathrm{CH}_{2} \mathrm{Ph}\right), 114.1$ (= $\left.\mathrm{CH}_{2}\right), 117.2,120.8\left(C_{5} \mathrm{H}_{4}\right), 121.4\left(C_{6} \mathrm{H}_{5}\right), 125.9\left(C_{6} \mathrm{H}_{5}\right)$, $127.3\left(C_{5} \mathrm{H}_{4}\right.$ ipso $), 128.5\left(C_{6} \mathrm{H}_{5}\right), 134.2(C \mathrm{H}=), 153.2$ $\left(C_{6} \mathrm{H}_{5}\right.$ ipso $)$. Anal. Found: C, 67.93; H, 7.30. Calc.: C, $68.08 ; \mathrm{H}, 7.34 \%$.

4.21. Synthesis of $\left[\mathrm{Zr}\left(\eta^{5}-\mathrm{C}_{5} \mathrm{H}_{5}\right)\left\{\eta^{5}-\mathrm{C}_{5} \mathrm{H}_{4} \mathrm{SiMe}_{2}\right.\right.$ $\left.\left.\left(\mathrm{CH}_{2} \mathrm{CH}=\mathrm{CH}_{2}\right)\right\}\left(\mathrm{CH}_{2} \mathrm{Ph}\right)_{2}\right](22)$

Diethyl ether $(100 \mathrm{ml})$ cooled to $-78{ }^{\circ} \mathrm{C}$ was added to a mixture of $\mathrm{MgBz}_{2} \cdot 2 \mathrm{THF}(0.92 \mathrm{~g}, 2.62 \mathrm{mmol})$ and $13(0.85 \mathrm{~g}, 2.18 \mathrm{mmol})$ and the suspension was stirred for $18 \mathrm{~h}$ while warming slowly to r.t. After filtration the $\mathrm{Et}_{2} \mathrm{O}$ was removed under reduced pressure and the residue extracted into $\mathrm{C}_{6} \mathrm{H}_{14}$ to separate the white insoluble solid. The solution was concentrated to 20 $\mathrm{ml}$ and cooled to $-35{ }^{\circ} \mathrm{C}$. Complex 22 was collected as a yellow orange solid and dried under vacuum. Yield: $0.92 \mathrm{~g}, 1.83 \mathrm{mmol}, 84 \% .{ }^{1} \mathrm{H}$ NMR $\left(300 \mathrm{MHz}, \mathrm{C}_{6} \mathrm{D}_{6}\right.$, $\left.25{ }^{\circ} \mathrm{C}\right): \delta 0.04\left(\mathrm{~s}, 6 \mathrm{H}, \mathrm{Si} M e_{2}\right), 1.48\left(\mathrm{~d}, 2 \mathrm{H}, J_{\mathrm{H}-\mathrm{H}}=8.6\right.$ $\left.\mathrm{Hz}, \mathrm{SiCH}_{2}\right), 1.89\left(\mathrm{~m}, 4 \mathrm{H}, \mathrm{ZrCH}_{2}\right), 4.88\left(2 \mathrm{~d}, 2 \mathrm{H},=\mathrm{CH}_{2}\right)$, $5.59(\mathrm{~m}, 1 \mathrm{H}, \mathrm{CH}=), 5.65\left(\mathrm{~s}, 5 \mathrm{H}, \mathrm{C}_{5} H_{5}\right), 5.82(\mathrm{~m}, 2 \mathrm{H}$, $\left.\mathrm{C}_{5} H_{4}\right), 5.88\left(\mathrm{~m}, 2 \mathrm{H}, \mathrm{C}_{5} H_{4}\right), 6.93-6.96,7.24(3 \mathrm{~m}, 10 \mathrm{H}$, $\mathrm{C}_{6} \mathrm{H}_{5}$ ). ${ }^{1} \mathrm{H}$ NMR $\left(500 \mathrm{MHz}, \mathrm{CD}_{2} \mathrm{Cl}_{2}, 25{ }^{\circ} \mathrm{C}\right): \delta 0.26(\mathrm{~s}$, $\left.6 \mathrm{H}, \mathrm{Si} M e_{2}\right), 1.66\left(\mathrm{~d}, 2 \mathrm{H}, \mathrm{SiCH}_{2}\right), 1.86,1.89(2 \mathrm{~d}, 4 \mathrm{H}$, $\left.\mathrm{ZrCH}_{2}\right), 4.83,4.86\left(2 \mathrm{~d}, 2 \mathrm{H},=\mathrm{CH}_{2}\right), 5.75(\mathrm{~m}, 1 \mathrm{H}, \mathrm{CH}=)$, $5.94\left(\mathrm{~s}, 5 \mathrm{H}, \mathrm{C}_{5} H_{5}\right), 6.12\left(\mathrm{~m}, 2 \mathrm{H}, \mathrm{C}_{5} H_{4}\right), 6.23(\mathrm{~m}, 2 \mathrm{H}$, $\left.\mathrm{C}_{5} H_{4}\right), 6.84-6.86,7.19\left(3 \mathrm{~m}, \mathrm{C}_{6} H_{5}\right) ;{ }^{13} \mathrm{C}$ NMR $(300$ $\left.\mathrm{MHz}, \mathrm{CD}_{2} \mathrm{Cl}_{2}, 25{ }^{\circ} \mathrm{C}\right): \delta-2.2(\mathrm{SiMe}), 25.4\left(\mathrm{SiCH}_{2}\right)$, $61.2\left(\mathrm{CH}_{2} \mathrm{Ph}\right), 112.9\left(C_{5} \mathrm{H}_{5}\right), 114.2\left(=\mathrm{CH}_{2}\right), 117.1\left(C_{5} \mathrm{H}_{4}\right.$ ipso $), 117.4\left(C_{5} \mathrm{H}_{4}\right), 120.6\left(C_{5} \mathrm{H}_{4}\right), 121.2,125.6,126.1$ $\left(C_{6} \mathrm{H}_{5}\right), 134.7(\mathrm{CH}=), 153.0\left(C_{6} \mathrm{H}_{5}\right.$ ipso $)$. Anal. Found: $\mathrm{C}$, 69.24; H, 6.57. Calc.: C, 69.40; H, 6.83\%.

\subsection{Synthesis of $\left[\mathrm{Zr}\left(\eta^{5}-\mathrm{C}_{5} \mathrm{H}_{5}\right)\left\{\eta^{5}-\mathrm{C}_{9} \mathrm{H}_{6} \mathrm{SiMe}_{2}\right.\right.$} $\left.\left.\left(\mathrm{CH}_{2} \mathrm{CH}=\mathrm{CH}_{2}\right)\right\}\left(\mathrm{CH}_{2} \mathrm{Ph}\right)_{2}\right](23)$

The same procedure described to prepare 19 was followed using $\mathrm{MgBz}_{2} \cdot 2 \mathrm{THF}(0.97 \mathrm{~g}, 2.76 \mathrm{mmol})$ and $14(1.013 \mathrm{~g}, 2.3 \mathrm{mmol})$ in $\mathrm{Et}_{2} \mathrm{O}(50 \mathrm{ml})$ to give complex 23 which was extracted into $\mathrm{C}_{6} \mathrm{H}_{14} / \mathrm{C}_{6} \mathrm{H}_{5} \mathrm{CH}_{3}$ (9:1) and isolated as an orange solid. Yield: $0.55 \mathrm{~g}, 1 \mathrm{mmol}, 43 \%$. ${ }^{1} \mathrm{H}$ NMR $\left(300 \mathrm{MHz}, \mathrm{C}_{6} \mathrm{D}_{6}, 25{ }^{\circ} \mathrm{C}\right): \delta 0.22(\mathrm{~s}, 3 \mathrm{H}$, $\mathrm{Si} M e_{2}$ ), 0.26 (s, 3H, Si $M e_{2}$ ), 1.22, 1.48, 1.71, 1.85 (4d, 
$\left.4 \mathrm{H}, J_{\mathrm{H}-\mathrm{H}}=10.7 \mathrm{~Hz}, \mathrm{CH}_{2} \mathrm{Ph}\right), 1.69\left(2 \mathrm{~d}, 2 \mathrm{H}, J_{\mathrm{H}-\mathrm{H}}=8.0\right.$ $\left.\mathrm{Hz}, \mathrm{SiCH}_{2}\right), 4.87\left(2 \mathrm{~m}, 2 \mathrm{H},=\mathrm{CH}_{2}\right), 5.40\left(\mathrm{~s}, 5 \mathrm{H}, \mathrm{C}_{5} H_{5}\right)$, $5.62(\mathrm{~m}, 1 \mathrm{H}, \mathrm{CH}=), 6.18,6.55,6.80-6.95,7.18-7.25$ $\left(C_{6} \mathrm{H}_{5}+C_{9} \mathrm{H}_{6}\right) .{ }^{1} \mathrm{H}$ NMR $\left(500 \mathrm{MHz}, \mathrm{CD}_{2} \mathrm{Cl}_{2}, 25{ }^{\circ} \mathrm{C}\right): \delta$ 0.40 (s, 3H, SiMe $), 0.46$ (s, 3H, Si $M e_{2}$ ), 1.03, 1.38, 1.57, $1.78\left(4 \mathrm{~d}, 4 \mathrm{H}, \mathrm{CH}_{2} \mathrm{Ph}\right), 1.84\left(2 \mathrm{~d}, 2 \mathrm{H}, \mathrm{SiCH}_{2}\right), 4.84(2 \mathrm{~m}$, $\left.2 \mathrm{H},=\mathrm{CH}_{2}\right), 5.51\left(\mathrm{~s}, 5 \mathrm{H}, \mathrm{C}_{5} H_{5}\right), 5.75(\mathrm{~m}, 1 \mathrm{H}, \mathrm{CH}=)$, $6.58,6.67-6.71,6.77-6.82,7.12-7.15,7.30,7.38,7.63$ $\left(\mathrm{m}, 16 \mathrm{H}, \mathrm{C}_{6} \mathrm{H}_{5}+\mathrm{C}_{9} H_{6}\right) ;{ }^{13} \mathrm{C}$ NMR $\left(300 \mathrm{MHz}, \mathrm{CD}_{2} \mathrm{Cl}_{2}\right.$, $\left.25{ }^{\circ} \mathrm{C}\right): \delta-1.9(\mathrm{SiMe}),-1.2(\mathrm{SiMe}), 25.2\left(\mathrm{SiCH}_{2}\right)$, 63.6, $64.4\left(\mathrm{CH}_{2} \mathrm{Ph}\right), 110.0\left(=\mathrm{CH}_{2}\right), 114.5\left(C_{5} \mathrm{H}_{5}\right), 134.9$ $(C \mathrm{H}=), 121.3,121.5,125.2,125.6,125.8,126.0,126.2$, $126.3,127.3,128.4,128.6,130.3,152.4\left(C_{6} \mathrm{H}_{5}+C_{9} \mathrm{H}_{6}\right)$. Anal. Found: C, 71.49; H, 6.72. Calc.: C, 71.81; H, $6.57 \%$.

4.23. NMR characterization of $\left[\mathrm{Zr}\left(\eta^{5}-\mathrm{C}_{5} \mathrm{H}_{5}\right)\left\{\eta^{5}-\mathrm{C}_{5} \mathrm{H}_{4}\right.\right.$ $\left.\left.\mathrm{SiMe}_{2}\left(\mathrm{CH}_{2} \mathrm{CH}=\mathrm{CH}_{2}\right)\right\}\left(\mathrm{CH}_{2} \mathrm{Ph}\right)\right]\left[\left(\mathrm{CH}_{2} \mathrm{Ph}\right) \mathrm{B}\right.$

$\left.\left(\mathrm{C}_{6} F_{5}\right)_{3}\right](\mathbf{2 4})$

An equimolar mixture of 22 and $\mathrm{B}\left(\mathrm{C}_{6} \mathrm{~F}_{5}\right)_{3}$ was charged into a teflon-valved NMR tube and after being cooled to $-78{ }^{\circ} \mathrm{C} \mathrm{CD}_{2} \mathrm{Cl}_{2}$ was transferred under vacuum. The NMR spectrum was recorded at variable temperature between 193 and $293 \mathrm{~K} \mathrm{[5].}{ }^{1} \mathrm{H}$ NMR (500 $\mathrm{MHz}, \mathrm{CD}_{2} \mathrm{Cl}_{2}, 193 \mathrm{~K}$ ): $\delta 0.31$ (s, 3H, SiMe $), 0.59$ (s, $3 \mathrm{H}, \mathrm{SiMe} 2), 1.81(\mathrm{~m}, 1 \mathrm{H},=\mathrm{CH} H$ trans $), 2.05,2.13(2 \mathrm{~m}$, $\left.2 \mathrm{H}, \mathrm{SiCH}_{2}\right), 2.70\left(\mathrm{~s}, \mathrm{CH}_{2} \mathrm{~B}\right), 2,78(\mathrm{~m}, 1 \mathrm{H},=\mathrm{CH}$ Hcis $)$, 2.88, $3.16\left(2 \mathrm{~d}, 2 \mathrm{H}, \mathrm{ZrCH}_{2}\right), 5.74,6.13,6.35,7.10(4 \mathrm{~m}$, $\left.4 \mathrm{H}, \mathrm{C}_{5} H_{4}\right), 6.16\left(\mathrm{~s}, 5 \mathrm{H}, \mathrm{C}_{5} H_{5}\right), 7.30(\mathrm{~m}, 1 \mathrm{H}, \mathrm{CH}=), 6.61$, 6.80-6.87, 7.10-7.17, 7.21, $7.49\left(\mathrm{C}_{6} H_{5}\right) .{ }^{13} \mathrm{C}$ NMR $(500$ $\left.\mathrm{MHz}, \mathrm{CD}_{2} \mathrm{Cl}_{2}, 193 \mathrm{~K}\right): \delta 1.4\left(\mathrm{Si} M e_{2}\right), 1.9\left(\mathrm{Si}_{M} e_{2}\right), 27.9$ $\left(\mathrm{SiCH}_{2}\right), 45.0\left(\mathrm{CH}_{2} \mathrm{Ph}\right), 91.3\left(=\mathrm{CH}_{2}\right), 109.2\left(C_{5} \mathrm{H}_{5}\right)$, $170.5(C \mathrm{H}=), 108.2,108.9,109.9,113.5,115.6,118.0$, $118.5,119.8,147.8\left(C_{5} \mathrm{H}_{4}+C_{6} \mathrm{H}_{5}\right)$.

4.24. NMR characterization of $\left[\mathrm{Zr}\left(\eta^{5}-\mathrm{C}_{5} \mathrm{H}_{5}\right)\left\{\eta^{5}-\right.\right.$ $\left.\left.\mathrm{C}_{9} \mathrm{H}_{6} \mathrm{SiMe}_{2}\left(\mathrm{CH}_{2} \mathrm{CH}=\mathrm{CH}_{2}\right)\right\}\left(\mathrm{CH}_{2} \mathrm{Ph}\right)\right]$

[( $\left.\left.\mathrm{CH}_{2} \mathrm{Ph}\right) \mathrm{B}\left(\mathrm{C}_{6} \mathrm{~F}_{5}\right)_{3}\right](\mathbf{2 5})$

An equimolar mixture of 23 and $\mathrm{B}\left(\mathrm{C}_{6} \mathrm{~F}_{5}\right)_{3}$ was charged into a teflon-valved NMR tube and after being cooled to $-78{ }^{\circ} \mathrm{C} \mathrm{CD}_{2} \mathrm{Cl}_{2}$ was transferred under vacuum. The NMR spectrum was recorded at variable temperature between 193 and $293 \mathrm{~K} .{ }^{1} \mathrm{H}$ NMR (500 $\mathrm{MHz}, \mathrm{CD}_{2} \mathrm{Cl}_{2}, 193 \mathrm{~K}$ ): $\delta 0.37$ (s, 3H, SiMe $), 0.66$ (s, 3H, $\left.\mathrm{SiMe}_{2}\right), 1.15(\mathrm{~m}, 1 \mathrm{H},=\mathrm{CH}$ cis $), 2.10\left(\mathrm{~d}, 1 \mathrm{H}, \mathrm{CH}_{2} \mathrm{Ph}\right)$, 2.29, $2.54\left(2 \mathrm{~m}, 2 \mathrm{H}, \mathrm{SiCH}_{2}\right), 2.74\left(\mathrm{sb}, \mathrm{CH}_{2} \mathrm{~B}\right), 3.12$ (d, $\left.1 \mathrm{H}, \mathrm{CH}_{2} \mathrm{Ph}\right), 3.32(\mathrm{~m}, 1 \mathrm{H},=\mathrm{CH} H$ trans $), 5.97(\mathrm{~s}, 5 \mathrm{H}$, $\left.\mathrm{C}_{5} H_{5}\right), 7.43(\mathrm{~m}, 1 \mathrm{H}, \mathrm{CH}=), 6.56,6.60,6.82-6.87,7.10$ 7.25, 7.28, 7.47, 7.56, 7.60, $7.75\left(\mathrm{~m}, 11 \mathrm{H}, \mathrm{C}_{6} H_{5}+\mathrm{C}_{9} H_{6}\right)$. ${ }^{13} \mathrm{C}$ NMR $\left(500 \mathrm{MHz}, \mathrm{CD}_{2} \mathrm{Cl}_{2}, 25{ }^{\circ} \mathrm{C}\right): \delta-2.5(\mathrm{SiMe})$, $1.9(\mathrm{SiMe}), 29.6\left(\mathrm{SiCH}_{2}\right), 48.0\left(\mathrm{CH}_{2} \mathrm{Ph}\right), 91.8\left(=\mathrm{CH}_{2}\right)$, $109.2\left(C_{5} \mathrm{H}_{5}\right), 173.1(\mathrm{CH}=), 95.6,105.3,111.4,112.0$, $113.3,121.6,123.4,127.7,129.2,130.5,131.3,131.7$, $149.0\left(C_{6} \mathrm{H}_{5}+C_{9} \mathrm{H}_{6}\right)$.
4.25. X-ray molecular structure determination of $\left[\mathrm{Ti}\left(\eta^{5}\right.\right.$ $\left.\mathrm{C}_{5} \mathrm{Me}_{5}\right)\left(\eta^{5}-\mathrm{C}_{5} \mathrm{H}_{4}\left\{\mathrm{SiMe}_{2}\left(\mathrm{CH}_{2} \mathrm{CH}=\mathrm{CH}_{2}\right)\right\} \mathrm{Cl}_{2}\right]$ (11)

Red crystals of compound $\mathbf{1 1}$ were obtained by cooling a concentrated pentane solution and a suitable sized crystal was sealed under argon in a Lindemann tube and mounted in an Enraf-Nonius CAD 4 automatic four-circle diffractometer with graphite monochromated Mo $K \alpha$ radiation $(\lambda=0.71073 \AA)$. Crystallographic and experimental details are summarized in Table 2. Data were collected at room temperature. Intensities were corrected for $\mathrm{Lp}$ in the usual manner. No absorption or extinction corrections were made. The structure was solved by direct methods (SHELXL-90) [14] and refined by least-squares against $F^{2}$ (shelXL-93) [15]. All non-hydrogen atoms were refined anisotropically, and the hydrogen atoms were introduced from geometrical calculations and refined using a riding model with fixed thermal parameters.

\subsection{Ethylene polymerization experiments}

All polymerization experiments were carried out in a 500-ml reactor charged with dry toluene and saturated

Table 2

Crystal, experimental data and structure refinement procedures for compound 11

\begin{tabular}{|c|c|}
\hline Empirical formula & $\mathrm{C}_{20} \mathrm{H}_{30} \mathrm{Cl}_{2} \mathrm{SiTi}$ \\
\hline$M_{\mathrm{w}}$ & 417.33 \\
\hline Crystal habit & prismatic \\
\hline Colour & red \\
\hline Symmetry & monoclinic, $P 2_{1} / c$ \\
\hline \multicolumn{2}{|l|}{ Unit cell dimensions } \\
\hline$a(\AA)$ & $14.468(1)$ \\
\hline$b(\AA)$ & $13.397(1)$ \\
\hline$c(\AA)$ & $12.104(1)$ \\
\hline$\beta\left({ }^{\circ}\right)$ & $113.27(1)$ \\
\hline$V\left(\AA^{3}\right)$ & $2155.2(3)$ \\
\hline$Z$ & 4 \\
\hline$D_{\text {calc }}\left(\mathrm{g} \mathrm{cm}^{-3}\right)$ & 1.286 \\
\hline$F(000)$ & 880 \\
\hline Crystal size & $0.25 \times 0.28 \times 0.30 \mathrm{~mm}$ \\
\hline$\mu\left(\mathrm{cm}^{-1}\right)$ & 7.01 \\
\hline Scan mode & $\omega / 2 \theta 2.16<\theta<25.96$ \\
\hline Reflections measured & 4442 \\
\hline Independent reflections & $4229\left(R_{\mathrm{int}}=0.022\right)$ \\
\hline Reflections observed & $2680(I>2 \sigma(I))$ \\
\hline Range of $h k l$ & $\begin{array}{l}-17<h<16,-16<k<0 \\
0<l<14\end{array}$ \\
\hline Standard reflections & 3 every 200 reflections \\
\hline Refinement method & full-matrix least-squares on $F^{2}$ \\
\hline Final $R$ indices $(I>2 \sigma(I))^{\text {a }}$ & $R_{1}=0.0676, w R_{2}=0.1760$ \\
\hline Weighting scheme & $\begin{array}{l}\operatorname{calc} \omega=1 / \\
{\left[\sigma^{2}\left(F_{\mathrm{o}}{ }^{2}\right)+(0.1230 P)^{2}+1.3289 P\right]} \\
\text { where } P=\left(F_{\mathrm{o}}{ }^{2}+2 F_{\mathrm{c}}{ }^{2}\right) / 3\end{array}$ \\
\hline $\begin{array}{l}\text { Largest difference peak and } \\
\text { hole }\left(\mathrm{e} \AA^{-3}\right)\end{array}$ & $0.612,-0.468$ \\
\hline Goodness-of-fit on $F^{2}$ & 1.039 \\
\hline
\end{tabular}

${ }^{a} R_{1}=\Sigma|| F_{\mathrm{o}}|-| F_{\mathrm{c}}|/ \Sigma| F_{\mathrm{o}} \mid ; w R_{2}=\left\{\left[\Sigma \omega\left(\left(F_{\mathrm{o}}^{2}-F_{\mathrm{c}}{ }^{2}\right]\left[\Sigma \omega\left(F_{\mathrm{o}}{ }^{2}\right)^{2}\right]\right\}^{1 / 2}\right.\right.$. 
bubbling ethylene for $30 \mathrm{~m}$ at $1 \mathrm{~atm}$, purified, first over $\mathrm{P}_{2} \mathrm{O}_{5}$ and then through $\mathrm{AlMe}_{3}$. Aliquots of toluene solutions of the cocatalyst MAO followed by the catalyst were injected having a total volume of $100 \mathrm{ml}$ of toluene. The pressure was maintained at $1 \mathrm{~atm}$ at $21{ }^{\circ} \mathrm{C}$ during the polymerization experiment. After a determined time the reaction was quenched by addition of $5 \mathrm{ml}$ of a methanol $\mathrm{HCl}$ solution $(5 \%)$. The suspensions were stirred for $24 \mathrm{~h}$, filtrated, washed with methanol and dried at $70{ }^{\circ} \mathrm{C}$ for $24 \mathrm{~h}$.

\section{Supplementary material}

Crystallographic data for the structure reported have been deposited with the Cambridge Crystallographic Data Center, CCDC No. 183146 for complex 11. Copies of this information may be obtained free of charge from The Director, CCDC, 12 Union Road, Cambridge, CB2 1EZ, UK (fax: +44-1223-336-033; e-mail: deposit@ ccdc.cam.ac.uk or www: http://www.ccdc.cam.ac. uk).

\section{Acknowledgements}

Financial support of our work by MCyT (Project MAT2001-1309) is gratefully acknowledged. G.H., G.M and J.C are grateful to to the Alexander von HumboldtStiftung, MEC and CAM for fellowships.

\section{References}

[1] (a) M.A. Giardello, M.S. Eisen, C.L. Stern, T.J. Marks, J. Am. Chem. Soc. 117 (1995) 12114;

(b) L. Jia, X. Yang, A. Ishihara, T.J. Marks, Organometallics 14 (1995) 3135;

(c) J.I. Amor, T. Cuenca, M. Galakhov, P. Royo, J. Organomet. Chem. 497 (1995) 127;

(d) Y.-X. Chen, C.L. Stern, S. Yang, T.J. Marks, J. Am. Chem. Soc. 118 (1996) 12451;

(e) A.H. Horton, Organometallics 15 (1996) 2675;

(f) T.L. Tremblay, S.W. Ewart, M.J. Sarsfield, M.C. Baird, Chem. Commun. (1997) 831;

(g) T. Cuenca, M. Galakhov, G. Jiménez, E. Royo, P. Royo, M. Bochmann, J. Organomet. Chem. 543 (1997) 209;

(h) L. Jia, X. Yang, C.L. Stern, T.J. Marks, Organometallics 16 (1997) 842 ;

(i) J.I. Amor, T. Cuenca, M. Galakhov, P. Gómez-Sal, A. Manzanero, P. Royo, J. Organomet. Chem. 535 (1997) 155;

(j) P.A. Deck, C.L. Beswick, T.J. Marks, J. Am. Chem. Soc. 120 (1998) 1772;

(k) Y.-X. Chen, M.V. Metz, L. Li, C.L. Stern, T.J. Marks, J. Am. Chem. Soc. 120 (1998) 6287;

(1) C.L. Beswick, T.J. Marks, Organometallics 18 (1999) 2410;

(m) M.L. Green, J. Sassmannshansen, Chem. Commun. (1999) 115 ;

(n) M. Dahlmann, G. Erker, M. Nissinen, R. Fröhlich, J. Am.
Chem. Soc. 121 (1999) 2820;

(o) E.A. Bijpost, M.A. Zuideveld, A. Meetsma, J.H. Teuben, J. Organomet. Chem. 551 (1998) 159.

[2] (a) R.F. Jordan, Adv. Organomet. Chem. 32 (1991) 325;

(b) T.J. Marks, Acc. Chem. Res. 25 (1992) 57;

(c) P.C. Möhring, N.J. Coville, J. Organomet. Chem. 479 (1994) 1 ;

(d) H.H. Brintzinger, D. Fischer, R. Mülhaupt, B. Rieger, R.M. Waymouth, Angew. Chem., Int. Ed. Engl. 34 (1995) 1143;

(e) M. Bochmann, J. Chem. Soc., Dalton Trans. (1996) 255;

(f) G.W. Coates, Chem. Rev. 100 (2000) 1223;

(g) L. Resconi, L. Cavallo, A. Fait, F. Piemontesi, Chem. Rev. 100 (2000) 1253;

(h) E.Y-X. Chen, T.J. Marks, Chem. Rev. 100 (2000) 1391;

(i) A.K. Rappe, W.M. Skiff, C.J. Casewit, Chem. Rev. 100 (2000) 1435.

[3] (a) M. Bochmann, S.J. Lancaster, O.B. Robinson, J. Chem. Soc., Chem. Commun. (1995) 2081;

(b) J. Ruwwe, G. Erker, R. Fröhlich, Angew. Chem., Int. Ed. Engl. 35 (1996) 80;

(c) Y. Sun, R.E.vH. Spence, M. Parvez, G.P.A. Yap, W.E. Piers, J. Am. Chem. Soc. 119 (1997) 5132;

(d) H.vH. Heijden, B. Hessen, A. Guy Orpen, Organometallics 120 (1998) 1112

[4] (a) Z. Wu, R.F. Jordan, J.L. Petersen, J. Am. Chem. Soc. 117 (1995) 5867 ;

(b) C.P. Casey, S.L. Hallenbeck, J.M. Wright, C.R. Landis, J. Am. Chem. Soc. 119 (1997) 9681;

(c) C.P. Casey, M.A. Fagan, S.L. Hallenbeck, Organometallics 17 (1998) 287;

(d) C.P. Casey, D.W. Carpenetti, H. Sakuri, J. Am. Chem. Soc. 121 (1999) 9483;

(e) C.P. Casey, D.W. Carpenetti, Organometallics 19 (2000) 3970; (f) J.-F. Carpentier, Z. Wu, C.W. Lee, S. Strömberg, J.N. Christopher, R.F. Jordan, J. Am. Chem. Soc. 122 (2000) 7750;

(g) S. Beck, S. Lieber, F. Schaper, A. Geyer, H.H. Brintzinger, J. Am. Chem. Soc. 123 (2001) 1483;

(h) C.G. Brandow, A. Mendiratta, J.E. Bercaw, Organometallics 20 (2001) 4253;

(i) C.P. Casey, D.W. Carpenetti, II, H. Sakurai, Organometallics 20 (2001) 4262;

(j) J.-F. Carpentier, J.P. Maryin, J. Luci, R.F. Jordan, J. Am. Chem. Soc. 123 (2001) 898;

(k) C.P. Casey, T.-Y. Lee, J.A. Tunge, D.W. Carpenetti, II, J. Am. Chem. Soc. 123 (2001) 10762;

(l) F. Schaper, A. Geyer, H.H. Brintzinger, Organometallics 21 (2002) 473.

[5] M.V. Galakhov, G. Heinz, P. Royo, Chem. Commun. (1998) 17.

[6] L.N. Maksimova, V.J. Koshutin, V.A. Smironov, Zh. Obshch. Khim. 43 (1973) 1198.

[7] T. Cuenca, P. Royo, Coord. Chem. Rev. 193-195 (1999) 447.

[8] R.D. Rogers, M.M. Benning, L.K. Kurihara, K.J. Moriarty, M.D. Rausch, J. Organomet. Chem. 293 (1985) 51.

[9] T.C. Mckenzie, R.D. Sanner, J.E. Bercaw, J. Organomet. Chem. 102 (1975) 457.

[10] E.P. Bierwagen, J.E. Bercaw, W.A. Goddard, III, J. Am. Chem. Soc. 116 (1994) 1481.

[11] G. Hidalgo, M. Mena, F. Palacios, P. Royo, R. Serrano, J. Organomet. Chem. 340 (1988) 37-40.

[12] E.C. Lund, T. Livinghouse, Organometallics 9 (1990) 2426.

[13] R.R. Schrock, J. Organomet. Chem. 122 (1976) 209.

[14] G.M. Sheldrick, Acta Crystallogr., Sect. A 46 (1990) 467.

[15] G.M. Sheldrick, SHELXL-97, University of Göttingen, Göttingen, Germany, 1997. 